\title{
Review Article \\ Palmitoylation as a Functional Regulator of Neurotransmitter Receptors
}

\author{
Vladimir S. Naumenko ${ }^{1}$ and Evgeni Ponimaskin $\mathbb{D}^{2}$ \\ ${ }^{1}$ Federal Research Center Institute of Cytology and Genetics, Siberian Division of the Russian Academy of Science, Novosibirsk, Russia \\ ${ }^{2}$ Cellular Neurophysiology, Hannover Medical School, Hannover, Germany \\ Correspondence should be addressed to Evgeni Ponimaskin; ponimaskin.evgeni@mh-hannover.de
}

Received 15 August 2017; Accepted 29 January 2018; Published 3 April 2018

Academic Editor: Christian Wozny

Copyright (c) 2018 Vladimir S. Naumenko and Evgeni Ponimaskin. This is an open access article distributed under the Creative Commons Attribution License, which permits unrestricted use, distribution, and reproduction in any medium, provided the original work is properly cited.

\begin{abstract}
The majority of neuronal proteins involved in cellular signaling undergo different posttranslational modifications significantly affecting their functions. One of these modifications is a covalent attachment of a 16-C palmitic acid to one or more cysteine residues (S-palmitoylation) within the target protein. Palmitoylation is a reversible modification, and repeated cycles of palmitoylation/depalmitoylation might be critically involved in the regulation of multiple signaling processes. Palmitoylation also represents a common posttranslational modification of the neurotransmitter receptors, including $G$ protein-coupled receptors (GPCRs) and ligand-gated ion channels (LICs). From the functional point of view, palmitoylation affects a wide span of neurotransmitter receptors activities including their trafficking, sorting, stability, residence lifetime at the cell surface, endocytosis, recycling, and synaptic clustering. This review summarizes the current knowledge on the palmitoylation of neurotransmitter receptors and its role in the regulation of receptors functions as well as in the control of different kinds of physiological and pathological behavior.
\end{abstract}

\section{Introduction}

Multiple neurotransmitters of the central nervous system (CNS) act through the activation of a huge variety of different receptors expressed on neurons and glial cells to modulate various aspects of human and animal behavior. The majority of the neurotransmitter receptors can be divided into two groups: (i) metabotropic or $\mathrm{G}$ protein-coupled receptors (GPCRs) and (ii) ionotropic receptors or ligand-gated ion channels (LICs) [1]. Signaling properties of the neurotransmitter receptors are under tight control of multiple factors regulating their functional activity and, hence, affecting behavior. One of these factors attracting increasing attention during the last decades includes posttranslational receptor modifications. Prominent examples of such modifications are glycosylation and phosphorylation. In addition, proteins can be modified by the covalent attachment of different lipid moieties such as GPI, myristate, palmitate, and stearate (i.e., protein lipidation). Among different classes of receptor lipidation, a special attention is paid to S-acylation-the covalent attachment of the long-chain fatty acid palmitate or stearate to cysteine residue(s) via thioester linkages. Since the modification with the palmitic acid (palmitoylation) is highly predominant among the S-acylated proteins, we will refer to this modification as palmitoylation throughout the text. In contrast to other types of lipidation, palmitoylation is a dynamic modification, and repeated cycles of palmitoylation/depalmitoylation are known to modulate different protein functions [2]. Generally, more than $70 \%$ of all known GPCRs contain the potential palmitoylation site(s) downstream of their seventh transmembrane domain, strongly suggesting that palmitoylation can represent a general feature of neurotransmitter receptors [3]. There are also a lot of experimental data providing direct experimental evidence for palmitoylation of neurotransmitter receptors. In many cases, the functional role of receptor palmitoylation was verified by creation and analysis of palmitoylation-deficient mutants (Table 1). More recently, proteomic approaches applied to study global palmitoylation of neuronal proteins have confirmed palmitoylation of endogenously expressed 
TABle 1: Palmitoylation sites and functions of neurotransmitter receptor palmitoylation.

\begin{tabular}{|c|c|c|c|c|c|}
\hline Receptor type & $\begin{array}{l}\text { Receptor } \\
\text { subtype }\end{array}$ & Palmitoylation site & Palmitoylation function & $\begin{array}{l}\text { Responsible } \\
\text { DHHC }\end{array}$ & Reference \\
\hline \multicolumn{6}{|c|}{ G protein-coupled receptors } \\
\hline \multirow{4}{*}{ Adrenergic } & $\alpha 1 \mathrm{AR}$ & $\mathrm{C} 120$ & $\begin{array}{l}\text { Receptor-mediated signaling and } \\
\text { receptor expression }\end{array}$ & DHHC21 & {$[58,59]$} \\
\hline & $\alpha 2 \mathrm{AR}$ & Cys 442 & $\begin{array}{l}\text { Receptor downregulation followed by } \\
\text { chronic agonist exposure }\end{array}$ & Unknown & {$[54,57]$} \\
\hline & $\beta 2 \mathrm{AR}$ & Cys341 & $\begin{array}{l}\text { Receptor phosphorylation and } \\
\beta \text {-arrestin binding; coupling to } \\
\text { the AC-mediated signaling and } \\
\text { desensitization }\end{array}$ & & {$[8,47,49-51]$} \\
\hline & & Cys265 & Receptor trafficking and localization & $\begin{array}{l}\text { DHHC9, } \\
\text { DHHC } 14 \text {, } \\
\text { DHHC } 18\end{array}$ & \\
\hline \multirow{3}{*}{ Serotonin } & $5-\mathrm{HT}_{1 \mathrm{~A}}$ & Cys417, Cys420 & $\begin{array}{l}\text { Gi protein coupling/effector signaling, } \\
\text { G } \beta \gamma \text {-mediated signaling }\end{array}$ & Unknown & {$[66]$} \\
\hline & $5-\mathrm{HT}_{4}$ & Cys328, Cys329 & $\begin{array}{l}\text { Regulation of constitutive } \\
\text { receptor activity }\end{array}$ & Unknown & {$[68]$} \\
\hline & $5-\mathrm{HT}_{7}$ & $\begin{array}{c}\text { Cys } 404, \text { Cys } 438, \\
\text { Cys } 441\end{array}$ & $\begin{array}{l}\text { Regulation of constitutive, } \\
\text { Gs-mediated receptor activity }\end{array}$ & Unknown & {$[68,75]$} \\
\hline \multirow{4}{*}{ Dopamine } & D1R & Cys347, Cys351 & $\begin{array}{l}\text { Receptor internalization and } \\
\text { functional activity }\end{array}$ & Unknown & {$[93,94]$} \\
\hline & $\mathrm{D} 2 \mathrm{R}$ & C443 & $\begin{array}{l}\text { Receptor surface expression and } \\
\text { stability }\end{array}$ & $\begin{array}{l}\text { DHHC3, } \\
\text { DHHC8, } \\
\text { DHHC4 }\end{array}$ & [95-97] \\
\hline & D3R & $\mathrm{C} 400$ & $\begin{array}{l}\text { Receptor localization on the } \\
\text { plasma membrane, endocytosis, } \\
\text { agonist binding }\end{array}$ & Unknown & {$[98]$} \\
\hline & $\mathrm{D} 4 \mathrm{R}$ & Cys467 & $\begin{array}{l}\text { Receptor cell surface expression, } \\
\text { signaling and endocytosis }\end{array}$ & Unknown & {$[100]$} \\
\hline \multirow[b]{2}{*}{ Vasopressin } & V1a & Cys371, Cys372 & $\begin{array}{l}\text { Receptor conformation and } \\
\text { phosphorylation }\end{array}$ & Unknown & [108] \\
\hline & $\mathrm{V} 2 \mathrm{R}$ & Cys341, Cys342 & $\begin{array}{l}\text { Receptor trafficking and localization } \\
\text { on the plasma membrane, agonist- } \\
\text { dependent receptor sequestration/ } \\
\text { internalization, and endocytosis }\end{array}$ & Unknown & {$[109-111]$} \\
\hline \multirow{3}{*}{ Adenosine } & $\mathrm{A}(1) \mathrm{AR}$ & Cys309 & $\begin{array}{c}\text { Receptor-effector coupling, } \\
\text { agonist-induced internalization/ } \\
\text { downregulation }\end{array}$ & Unknown & [118] \\
\hline & A2BAR & Cys311 & $\begin{array}{l}\text { Receptor conformation and } \\
\text { interaction with different proteins } \\
\text { related to sorting and signaling }\end{array}$ & Unknown & {$[121]$} \\
\hline & $\mathrm{A}(3) \mathrm{AR}$ & Cys305 & $\begin{array}{l}\text { Receptor recycling to the plasma } \\
\text { membrane after agonist removal }\end{array}$ & Unknown & {$[119]$} \\
\hline \multirow[t]{2}{*}{ Opioid } & $\mu$-Opioid & $\mathrm{C} 170$ & $\begin{array}{l}\text { Receptor homodimerization and } \\
\text { G protein coupling/activation }\end{array}$ & $\begin{array}{l}\text { DHHC3, } \\
\text { DHHC4 }\end{array}$ & [126-128] \\
\hline & $\delta$-Opioid & Unknown & Receptor trafficking and/or localization & Unknown & [129] \\
\hline Cannabinoid & $\mathrm{CB}(1)$ & Cys415 & $\begin{array}{l}\text { Receptor conformation, trafficking } \\
\text { and localization }\end{array}$ & Unknown & {$[6,136]$} \\
\hline Acetylcholine & Muscarinic & Cys457 & Receptor interaction with $\mathrm{G}$ protein & Unknown & [143] \\
\hline Neuropeptide Y & $\mathrm{Y}(1)$ & Cys337 & $\begin{array}{l}\text { Receptor conformation, } \mathrm{G} \text { protein } \\
\text { coupling, desensitization }\end{array}$ & Unknown & [149] \\
\hline Melatonin & $\begin{array}{l}\operatorname{MT}(1) \\
\operatorname{MT}(2)\end{array}$ & Cys7.72, Cys7.77 & $\begin{array}{l}\text { Receptor functioning toward } \\
\text { cAMP inhibition }\end{array}$ & Unknown & {$[156]$} \\
\hline
\end{tabular}


TABle 1: Continued.

\begin{tabular}{|c|c|c|c|c|c|}
\hline Receptor type & $\begin{array}{l}\text { Receptor } \\
\text { subtype }\end{array}$ & Palmitoylation site & Palmitoylation function & $\begin{array}{l}\text { Responsible } \\
\text { DHHC }\end{array}$ & Reference \\
\hline \multicolumn{6}{|c|}{ Ligand-gated ion channels } \\
\hline \multirow[t]{3}{*}{ Glutamate } & NMDA & $\begin{array}{l}\text { Cysteine clusters in the } \\
\text { C-terminus of GluN2A and } \\
\text { GluN2B subunits. The first } \\
\text { cluster-GluN2A: C848, } \\
\text { C853, and C870; and } \\
\text { GluN2B: C849, C854, } \\
\text { and C871. The second } \\
\text { cluster-GluN2A: C1214, } \\
\text { C1217, C1236, and C1239; } \\
\text { and GluN2B: C1215, C1218, } \\
\text { C1239, C1242, and C1245 }\end{array}$ & $\begin{array}{l}\text { Receptor retention in the Golgi } \\
\text { apparatus, trafficking and surface } \\
\text { expression/internalization }\end{array}$ & DHHC3 & {$[4,176,177]$} \\
\hline & AMPA & C610, C836 & $\begin{array}{l}\text { Subunit-specific receptors regulation } \\
\text { and trafficking }\end{array}$ & $\begin{array}{l}\text { DHHC2, } \\
\text { DHHC3 }\end{array}$ & {$[170,172,202]$} \\
\hline & Kainate & C827 and C840 & $\begin{array}{l}\text { Receptor insertion and stabilization } \\
\text { at the cell surface }\end{array}$ & Unknown & {$[178,179]$} \\
\hline GABA & GABAA & $\begin{array}{l}\text { Multiple cysteine residues } \\
\text { within the major intracellular } \\
\text { domain of gamma2 subunit }\end{array}$ & $\begin{array}{l}\text { Synaptic clustering of receptor, cell } \\
\text { surface expression, and trafficking }\end{array}$ & $\begin{array}{l}\text { DHHC3, } \\
\text { DHHC7 }\end{array}$ & [187-189] \\
\hline Acetylcholine & $\begin{array}{c}\text { Nicotinic } \\
\alpha 4\end{array}$ & Cys273 & $\begin{array}{c}\text { Receptor total and cell surface } \\
\text { expression }\end{array}$ & Unknown & [197] \\
\hline Adenosine & $\mathrm{P} 2 \mathrm{X} 7$ & $\begin{array}{l}\text { Cys371, 373, 374, 477, 479, } \\
482,498,499,506,572,573\end{array}$ & $\begin{array}{l}\text { Receptor trafficking and plasma } \\
\text { membrane localization; receptor } \\
\text { macromolecular organization }\end{array}$ & Unknown & [200] \\
\hline
\end{tabular}

neurotransmitter receptor under in vivo conditions [4, 5]. Disruption of palmitoylation could significantly affect a variety of neurotransmitter receptors properties, including conformation $[6,7]$, trafficking and localization on the plasma membrane $[8,9]$, and downstream signaling [10, 11]. This review summarizes our current knowledge on the palmitoylation of neurotransmitter receptors and its role in the regulation of receptors functions and, as consequence, in the control of different kinds of physiological and pathological behavior.

\section{Enzymology of Receptor Palmitoylation}

Palmitoylation is catalyzed by a family of palmitoyl acyltransferases (PATs) that contain a conserved DHHC (Asp-His-His-Cys) cysteine-rich domain directly involved in the palmitoyl-transfer reaction. The DHHC-motif is embedded within a 51-amino acid domain that is a variant of the $\mathrm{C} 2 \mathrm{H} 2$ zinc finger motif. A multitude of DHHC proteins exist in eukaryotic cells, seven in yeast and 23 in humans [12-14]. Besides the cysteine-rich domain, little sequence conservation exists between DHHC proteins. Their size varies from 263 to 765 amino acids, and the number of (predicted) transmembrane regions-from four to six $[15,16]$. Most DHHC proteins are expressed in multiple tissues, but some of them are expressed in only defined cell types. For example, DHHC2 is expressed only in kidney and testis, whereas DHHC11 is expressed exclusively in testis [17]. The majority of DHHC proteins are localized at endoplasmic reticulum (ER) and Golgi membranes, with a small number targeted to the plasma membrane, endosomes, and synaptic vesicles $[18,19]$. Various studies including our own analyzed the alteration in the palmitoylation level of substrate proteins upon overexpression with $\mathrm{DHHC}$ proteins or upon shRNA-mediated inhibition of DHHC expression. By the use of such assays, it was shown that most proteins can be palmitoylated by several but not each of the various DHHC proteins, indicating that the 23 enzymes show distinct but overlapping substrate specificities [12, 20-22]. It is assumed that there are multiple recognition elements in a substrate protein and that sequence variation within and outside the cysteine-rich domain determines the substrate specificity of DHHC proteins [23]. In several cases, domains affecting the recruitment of specific substrates were identified experimentally [18, 24-27]. Very recently, two novel noncanonical endocytic signals were identified within the C-terminus of $\mathrm{zDHHC2}$, the PAT responsible for palmitoylation of AKAP79/150 and PSD95 [28]. Mutation of these signals enhanced plasma membrane accumulation of $\mathrm{zDHHC} 2$ in both $\mathrm{PC} 12$ cells and neurites of rat hippocampal neurons. In addition, authors demonstrated a potential role of phosphorylation for functional modulation of these regulatory domains. Also the first high-resolution crystal structure of the complex between the ankyrin-repeat domain of neuronal DHHC17 and its canonical substrate Snap25b was experimentally solved [29]. This study not only revealed the structural basis of interaction between PAT and its substrate but also demonstrated the role of critical 
residues for substrate binding and palmitate transfer and show the involvement of the same residues in binding huntingtin, another important substrate of DHHC17 [29]. DHHCs may also differ in their acyl-CoA specificity, explaining S-acylation of proteins with different fatty acids $[23,30]$. For example, it was shown that DHHC2 can efficiently transfer acyl-chains of 14 carbon atoms and longer, whereas DHHC3 activity was greatly reduced when acyl-CoAs with chain lengths longer than 16 carbon atoms were provided as substrates. As mentioned above, S-acylated proteins are predominantly modified with palmitate, although protein modifications with stearate, arachidonate, and eicosapentaenoate has been demonstrated as well $[31,32]$. To date, PATs responsible for palmitoylation of 6 different neurotransmitter receptors, including 4 GPCRs and 2 LICs, were identified experimentally (Table 1 , see also text below).

Palmitoylation can be reversed by the action of thioesterases that remove the acyl moiety bound from the cysteine. Three cytosolic and 2 lysosomal thioesterases have been identified, including the acyl-protein thioesterases APT1, APT2, and APT1-like and the palmitoyl-protein thioesterases PPT1 and PPT2, respectively [33]. Furthermore, recent studies described the isolation of 38 serine hydrolases from mouse (so-called ABHD proteins) with depalmitoylating activity [34, 35]. The physiological importance of the PAT enzymes has been mainly studied in the field of neurobiology, as alterations of their function often result in severe disease, such as Alzheimer's and Huntington's disease, schizophrenia, and mental retardation [18]. Thus, DHHCs represent a potential target for treatment of multiple diseases, and drugs against DHHC proteins are currently under development [36]. At the same time, there are some data on the functional roles of palmitoylation of different neurotransmitter receptors, indicating the involvement of this modification in the mechanisms underlying different types of normal and pathological behavior. For example, it was shown that palmitoylation of the NMDARs could play a role in the mechanisms of pain [37], and palmitoylation of defined AMPA receptor subunits controls psychomotor sensitivity to the psychoactive drug in vivo via regulation of receptor trafficking and subcellular localization [9].

\section{Palmitoylation of G Protein-Coupled Receptors (GPCRs)}

3.1. Adrenergic Receptors. Adrenoreceptors belong to the GPCR adrenoceptor family and are activated by the catecholamines norepinephrine and epinephrine. Based on their pharmacological characteristics, adrenoceptors were originally divided into two major types, alpha and beta. The current classification includes three major receptor types, alpha1 adrenoceptors ( $\alpha 1 \mathrm{ARs}$ ), alpha-2 adrenoceptors ( $\alpha 2 \mathrm{ARs}$ ), and beta adrenoceptors ( $\beta$ ARs) [38]. The $\alpha 1$ ARs are coupled to $\mathrm{Gq}$ protein, while $\alpha 2 \mathrm{ARs}$ receptors activate inhibitory $\mathrm{Gi}$ protein. The $\beta$ ARs, which are composed of three subtypes $\beta 1, \beta 2$, and $\beta 3$, are linked to Gs proteins, although the $\beta 2 \mathrm{AR}$ isoform also couples to inhibitory Gi proteins. Adrenoreceptors are implicated in diverse physiological functions, including modulation of the cardiovascular, endocrine, renal, and pulmonary systems [39]. In the CNS, adrenoreceptors are involved in the regulation of different kinds of normal and pathological behavior, including aggression [40], sexual behavior [41], emotional regulation of pain [42], attentiondeficit/hyperactivity disorder [43], drug addiction [44], antidepressant drug action [45], and Parkinson's disease [46].

The $\beta 2 A R$ was the first GPCR for which palmitoylation was demonstrated experimentally [47]. After this pioneering study, multiple aspects of $\beta 2 \mathrm{AR}$ palmitoylation were investigated in great details in more than 20 follow-up publications. In the initial work by O'Dowd et al., authors identified Cys341 in the receptor's C-terminal domain as a palmitoylation site and demonstrated a crucial role of $\beta 2 \mathrm{AR}$ palmitoylation in the normal coupling of the receptor to the adenylyl cyclase (AC) signaling. A follow-up study by the same group demonstrated that receptor stimulation leads to transient increase in palmitoylation mediated by the increased palmitate turnover $[10,11]$. It is noteworthy that palmitoylation of the $\beta 2 \mathrm{AR}$ at Cys341 as well as agonistmediated increase in palmitate turnover was recently confirmed by the mass spectrometric analysis [48]. Moreover, nonpalmitoylated $\beta 2 \mathrm{AR}$ mutant has undergone an increased phosphorylation and is uncoupled from Gs protein. Also the receptor desensitization was largely affected by the disruption of palmitoylation [49-51]. In addition, palmitoylation of $\beta 2 \mathrm{AR}$ seems to play an important role in complex building between receptor and $\beta$-arrestin [52]. Palmitoylation of $\beta 2 \mathrm{AR}$ is also involved in the modulation of $\beta$-adrenergic signaling pathway by nitric oxide $(\mathrm{NO})$ in the way that NO decreased receptor palmitoylation [53]. Surprisingly that after more than 25 years' intensive analysis of $\beta 2 \mathrm{AR}$ palmitoylation, Adachi et al. recently identified Cys265 within the third intracellular loop as a novel palmitoylation site [8]. While basal palmitoylation of Cys265 is extremely low, receptor stimulation results in enhanced palmitoylation at this position. Functionally, palmitoylation of Cys265 may stabilize receptor at the plasma membrane, thus playing a role in the $\beta 2 \mathrm{AR}$ trafficking and localization. Palmitoylation of this atypical cysteine residues is mediated by the Golgi-resident palmitoyl transferases zDHHC9/14/ 18 and is followed by depalmitoylation via the plasma membrane-localized acyl-protein thioesterase APT1 [8]. Because Cys 265 is not conserved in $\beta 1 \mathrm{AR}$, the authors suggested that selective palmitoylation of $\beta 2 \mathrm{AR}$ at Cys 265 may be associated with functional differences between $\beta 2 \mathrm{AR}$ and $\beta 1 \mathrm{AR}$, in particular with those dealing with resistance of $\beta 2 \mathrm{AR}$ to downregulation.

The palmitoylation of the adrenergic receptors belonging to the $\alpha 2 \mathrm{AR}$ group was extensively investigated as well. In 1993, Kennedy and Limbird demonstrated that $\alpha 2 \mathrm{AR}$ is palmitoylated and that replacement of C-terminal Cys 442 eliminates detectable palmitoylation without perturbing receptor coupling to $\mathrm{Gi}$ protein [54]. In the follow-up study, the same authors demonstrated that palmitoylation of the $\alpha 2 \mathrm{AR}$ is a dynamic process regulated by agonist, and that sequence distal to Cys442 is not required for palmitoylation [55]. Surprisingly, regulation of receptor palmitoylation by agonist was not confirmed in the most recent study, in which palmitoylation of the fusion protein 
between the $\alpha 2 \mathrm{AR}$ and the alpha subunit of the Go protein was analyzed [56]. In this study, the authors found that regulation of palmitoylation by the agonist occurred only for the $G$ protein. Moreover, functional analysis of the $\alpha 2 \mathrm{AR}$ palmitoylation showed that palmitoylation was specifically involved in agonist-promoted receptor downregulation upon chronic agonist exposure without affecting other receptor functions [57].

More recently, $\alpha 1 \mathrm{AR}$ has also been shown to undergo palmitoylation [58]. In this study, authors demonstrated that zDHHC21 forms a complex with the $\alpha 1 \mathrm{DAR}$ and can thus be PAT responsible for the receptor palmitoylation. Analysis of the vascular functions in a mouse expressing a nonfunctional ZDHHC21 (F233A) revealed diminished functions of vascular $\alpha 1 \mathrm{AR}$, leading to hypotension and tachycardia mediated by the reduced vascular tone [58]. Although this study was focused on the functional role of palmitoylation of peripheral $\alpha 1 \mathrm{ARs}$, it can also have implications for $\alpha 1$ ARs expressed in the brain, where these receptor are critically involved in the regulation of cognitive functions and behavioral activation [59].

3.2. Serotonin Receptors. Serotonin (5-hydroxytryptamine or $5-\mathrm{HT}$ ) is an important neurotransmitter involved in the regulation of different physiological functions, including most of the forms of normal and pathological behavior. Multiple effects of 5-HT are mediated by the existence of 14 serotonin receptor subtypes. With exception of the $5-\mathrm{HT}_{3}$ receptor, that is, LIC, all other 5-HT receptors belong to the GPCR family. Palmitoylation of four 5-HT receptors, including 5$\mathrm{HT}_{1 \mathrm{~A}}, 5-\mathrm{HT}_{1 \mathrm{~B}}, 5-\mathrm{HT}_{4}$, and $5-\mathrm{HT}_{7}$, was experimentally confirmed. More recently, proteomic approaches using a global, site-specific analysis of neuronal protein S-acylation have uncovered $5-\mathrm{HT}_{2 \mathrm{~A}}$ receptor as a putative palmitoylated protein [5]. Moreover, 5- $\mathrm{HT}_{2 \mathrm{~B}}$ and $5-\mathrm{HT}_{6}$ receptors contain potential palmitoylation sites within their C-terminus, although palmitoylation of these receptors was not demonstrated experimentally.

Among serotonin receptors, the $5-\mathrm{HT}_{1 \mathrm{~A}}$ receptor attracts particular attention because of its key role in the regulation of the brain 5-HT system functioning [60]. There are also a lot of data on the role of $5-\mathrm{HT}_{1 \mathrm{~A}}$ receptor in the mechanisms underlying aggression [61], anxiety [62], depression [62, 63], depressive psychosis [64], and suicidal behavior [65]. The 5- $\mathrm{HT}_{1 \mathrm{~A}}$ receptor is palmitoylated at its C-terminal Cys417 and Cys420 residues [66]. In contrast to other palmitoylated GPCRs that usually undergo repeated cycles of palmitoylation/depalmitoylation, $5-\mathrm{HT}_{1 \mathrm{~A}}$ receptor palmitoylation is irreversible and insensitive to the agonist stimulation [66]. Functionally, palmitoylation of 5- $\mathrm{HT}_{1 \mathrm{~A}}$ receptor is necessary for its communication with the Goisubunits. Furthermore, nonpalmitoylated mutants failed to inhibit cAMP formation and activate mitogen-activated protein kinase (MAPK), demonstrating the importance of receptor palmitoylation for the downstream effector signaling [66]. The underlying molecular mechanism might include mislocalization of the receptor within the plasma membrane: While the wild-type $5-\mathrm{HT}_{1 \mathrm{~A}}$ receptors are preferentially localized within the membrane rafts, nonpalmitoylated mutants are excluded from this membrane subdomain [67], which is known to act as a signaling "hot spot" [68].

In addition to the $5-\mathrm{HT}_{1 \mathrm{~A}}$ receptor, the $5-\mathrm{HT}_{1 \mathrm{~B}}$ receptor has also been shown to be palmitoylated [69]. Although the functional role of $5-\mathrm{HT}_{1 \mathrm{~B}}$ receptor palmitoylation was not experimentally elucidated, the high homology between 5$\mathrm{HT}_{1 \mathrm{~A}}$ and $5-\mathrm{HT}_{1 \mathrm{~B}}$ receptors suggests that palmitoylation of the $5-\mathrm{HT}_{1 \mathrm{~B}}$ receptor can be critically involved in the regulation of its functions.

Another palmitoylated serotonin receptor is the $5-\mathrm{HT}_{4}$ receptor. In the mammalian brain, the $5-\mathrm{HT}_{4}$ receptor is involved in the control of acetylcholine and dopamine secretion, facilitates cognitive performance, and is also implicated in learning and memory. This receptor also plays a role in the mechanisms underlying anxiety [70], neurodegenerative diseases, major depressive disorder, and anorexia $[71,72]$. Palmitoylation of the $5-\mathrm{HT}_{4}$ receptor is a reversible modification, and receptor stimulation increases the turnover rate for receptor-bound palmitate [73]. In addition to highly conserved cysteine residue Cys328/Cys329, presented in all 5- $\mathrm{HT}_{4}$ receptor isoforms, Cys386 within the C-terminal domain of $5-\mathrm{HT}_{4(\mathrm{a})}$ receptor isoform was identified as an additional palmitoylation site [74]. From the functional point of view, $5-\mathrm{HT}_{4}$ receptor palmitoylation has been shown to not be involved in the $G$ protein coupling as well as in receptor trafficking. However, mutation of Cys328/ Cys329 resulted in a significant increase of the receptor's constitutive activity, suggesting that dynamic palmitoylation of the $5-\mathrm{HT}_{4}$ receptor could affect isomerization of the receptor from inactive to active form by formation of an additional cytoplasmic loop [68]. It is noteworthy that the C328S/C329S mutant exhibited enhanced receptor phosphorylation under basal conditions and after agonist stimulation. This mutant was also more effectively desensitized and internalized via a $\beta$-arrestin-mediated pathway, when compared with the wild-type receptor [68].

More recently, we have found that the mouse $5-\mathrm{HT}_{7(\mathrm{a})}$ receptor isoform undergoes palmitoylation as well [75]. The $5-\mathrm{HT}_{7}$ receptor is associated with a number of physiological and pathophysiological responses, including age-dependent changes of the circadian timing [76] and phase shifting of the circadian rhythm [77]. In addition, a large body of evidence indicates an involvement of the $5-\mathrm{HT}_{7}$ receptor in the development of anxiety and depression [78]. At the cellular level, the $5-\mathrm{HT}_{7}$ receptor was shown to modulate the neurite outgrowth, synaptogenesis, and neuronal excitability $[79,80]$. The $5-\mathrm{HT}_{7}$ receptor is dynamically palmitoylated in an agonist-dependent manner, and its C-terminal cysteine residues Cys404 and Cys438/Cys441 were identified as potential palmitoylation sites [75]. Functional analysis of palmitoylation-deficient mutants revealed that palmitoylation of the $5-\mathrm{HT}_{7}$ receptor was not involved in an agonistinduced activation of Gs and G12 proteins. In contrast, mutation of the Cys404 (either alone or in combination with Cys438 and Cys441) resulted in significantly increased constitutive, agonist-independent $5-\mathrm{HT}_{7}$ receptor activity. It is noteworthy that only the activation of Gs-mediated pathway was increased, whereas the activation of $\mathrm{G} \alpha 12$-protein was not affected [75]. 
3.3. Dopamine Receptors. Dopamine plays a crucial role in the regulation of various physiological processes, including executive function, learning, reward, motivation, and neuroendocrine control [81]. Dysfunction of dopaminergic signaling may be involved in multiple neuronal disorders such as central fatigue [82], tardive dyskinesia [83], Parkinson's [84] and Alzheimer's disease [85], major depression [86], and schizophrenia [87]. Moreover, medications which increase the dopamine level in the brain by inhibiting dopamine reuptake or stimulation of defined dopamine receptors have been proven to be potent antidepressants $[88,89]$.

Dopamine operates through the activation of five distinct GPCRs that are divided into two major groups: D1 and D2. The D1 family consists of D1 and D5 receptors, which are coupled to the stimulatory Gs protein to activate AC. The members of the D2 family, including D2, D3, and D4 receptors, mediate Gi protein-mediated inhibition of AC [90]. Palmitoylation of the recombinant D1 receptor was demonstrated more than 20 years ago using an overexpression of recombinant receptor in the baculovirus system [91]. In the same study, the authors have shown that receptor stimulation resulted in an increased level of $\left[{ }^{3} \mathrm{H}\right]$-palmitate incorporation into the receptor. Studies on the functional role of D1 receptor palmitoylation revealed that substitution of palmitoylated cysteines Cys347 and Cys351 by alanine failed to affect the receptor affinity for agonists as well as receptor ability to stimulate AC $[92,93]$. More recently, Kong et al. demonstrated that palmitoylation of D1 receptor is critically involved in agonist-dependent receptor internalization [94].

Both short and long isoforms of D2 receptor (D2S and D2L) have also been shown to be palmitoylated $[95,96]$. Functionally, palmitoylation of D2L, which takes place at Cys443, is involved in the regulation of receptor stability and trafficking to the plasma membrane [97]. In this study, palmitoyl acyltransferase (PAT) DHHC4 was identified as a D2L interaction partner, suggesting that this PAT might be responsible for receptor palmitoylation. The D3 receptor also undergoes posttranslational palmitoylation, which is involved in the regulation of multiple receptor functions, including cell surface expression, protein kinase C-mediated endocytosis, agonist affinity, and agonistinduced receptor tolerance [98]. This study also revealed that although C-terminal domains of D2 and D3 receptors possess a high homology, D3 receptor is palmitoylated more extensively. Based on these findings, authors suggested that regulated palmitoylation may represent a new strategy for selective modulation of D3 receptor. This assumption is extremely important due to the fact that D2 and D3 receptors are the main targets of currently used neuroleptic drugs. The most serious side effects of the currently used antipsychotics are disturbances in motor functions [99]. Since D2 and D3 receptors are heavily expressed in the regions responsible for motor and emotion-related mental functions, respectively, development of D3 receptor-specific ligands or selective manipulation of the specific signaling pathways of D3 receptor can be used as a strategy to separate the desired therapeutic antipsychotic activities from side effects on motor function.
Also the last member of the D2 receptor family, D4 receptor, is palmitoylated on its terminal cysteine residue Cys467. Similar to that of the D3 receptor, palmitoylation of D4 receptor has been shown to regulate a receptor's cell surface expression, signaling, and endocytosis [100].

3.4. Vasopressin Receptors. The hormone arginine vasopres$\sin (\mathrm{AVP})$, which is produced in the neurohypophysis, plays an important role in a wide range of physiological functions, including water reabsorption, cardiovascular homeostasis, and endocrine functions [101]. AVP works not only as a peripheral hormone but also as a neuropeptide influencing multiple brain functions such as regulation of memory [102]; maternal care and anxiety-related behavior [103]; and parental, social, and sexual behavior [104, 105] as well as aggressive behavior [106]. These and other actions of AVP are mediated by three vasopressin receptor subtypes-V1a, V1b, and V2-whereas only V1 receptor isoforms are expressed in the CNS (with the exception of an autoregulatory V2 receptor expressed exclusively on the AVP neurons) [107]. V1a and V1b receptors couple to the Gq protein to regulate phospholipase C (PLC) pathway, and the V2 receptor couples to the Gs protein [101].

The V1a receptor (V1aR) is palmitoylated on Cys371 and Cys372 located in the C-terminal receptor domain [108], and palmitoylation of the V1aR is a reversible modification regulated by AVP. While receptor affinity to ligands as well as intracellular signaling was not affected by the nonpalmitoylated mutants, receptor phosphorylation under both basal and AVP-stimulated conditions was abolished compared to the wild-type V1aR. Moreover, the nonpalmitoylated receptor was sequestered at a faster rate [108].

In the vasopressin V2 receptor (V2R), conserved cysteine residues at positions 341 and 342 were identified as putative acylation sites $[109,110]$. The V2R is palmitoylated on both cysteine residues, and each cysteine is palmitoylated independently from the other $[109,110]$. Functional analysis of palmitoylation-deficient mutants revealed that ligand binding affinity, AVP-induced AC stimulation, receptor internalization, and desensitization were not affected by the absence of palmitoylation $[109,110]$. However, V2R palmitoylation was important for the intracellular receptor trafficking and localization on the plasma membrane [109]. A later study by Charest and Bouvier demonstrated that prevention of the V2R palmitoylation by site-directed mutagenesis significantly slows down agonist-promoted receptor endocytosis. Moreover, V2R-mediated activation of MAPK was reduced in the case of nonpalmitoylated receptor mutant [111]. The authors also investigated a possible interplay between receptor endocytosis and vasopressin-stimulated MAPK activity and found that the reduced kinase activation obtained by the palmitoylation-deficient mutant was not mediated by the altered receptor endocytosis [111].

3.5. Adenosine Receptors. Adenosine acts as a neurotransmitter in the brain by activating four specific GPCRs, including $\mathrm{A} 1, \mathrm{~A} 2 \mathrm{~A}, \mathrm{~A} 2 \mathrm{~B}$, and $\mathrm{A} 3$ receptors. Stimulation of the $\mathrm{A} 2 \mathrm{~A}$ and $\mathrm{A} 2 \mathrm{~B}$ adenosine receptors (ARs) increases 
cAMP production via Gs protein, resulting in activation of protein kinase A (PKA) and phosphorylation of the cAMP response element binding protein (CREB). In contrast, activation of the $\mathrm{A} 1$ and $\mathrm{A} 3$ ARs inhibits cAMP production and decreases PKA activity and CREB phosphorylation [112]. In addition, A1AR can facilitate phospholipase C (PLC) activity through the activation of the Gq protein. ARs are known to be involved in the mechanisms underlying different forms of normal and pathological behavior, including social behavior and anxiety $[113,114]$, avoidance learning [115], mood and memory dysfunction triggered by chronic stress [116], and cognitive impairment [117].

The human A1AR is palmitoylated at the C-terminal cysteine residue Cys309, and the palmitoylation level is not influenced by the agonist stimulation [118]. It is noteworthy that various receptor functions, including the kinetics of agonist-induced receptor downregulation, coupling of receptor to Gi protein, and activation of the downstream effectors, such as GIRK1 and CIR $\mathrm{K}^{+}$channels, were not affected by substitution of this cysteine with either serine or alanine [118]. Interestingly, substitution of the homologous cysteine residue Cys305 within the $\mathrm{C}$-terminus of the A3AR resulted in significantly faster agonist-mediated internalization of this mutant compared with the wild type, although analogous mutation of the human A1AR (Cys309Ala) had no effect on receptor internalization [119]. Moreover, unlike the wild-type $\mathrm{A} 3 \mathrm{AR}$ and nonpalmitoylated $\mathrm{A} 1 \mathrm{AR}$, the entire pool of internalized nonpalmitoylated A3AR mutant was able to recycle back to the plasma membrane after agonist removal. This effect was mediated by the subtype-specific differences in the $\beta$-arrestin recruitment correlating with the sensitivity of the receptor's C-terminus to GRK phosphorylation. Together, these results suggest that in the case of the A3AR, sensitivity to GRK-mediated internalization might be regulated by the palmitoylation upstream of the GRK phosphorylation $[119,120]$.

The A2BAR also contains conserved cysteine residue at position 311, which has been suggested to undergo palmitoylation. Homology modeling, molecular docking, and molecular dynamic simulations of A2BAR revealed that palmitoylation can bend the proximal portion of the receptor's C-terminal tail toward the membrane, leading to a deeper insertion into the lipid bilayer [121]. In addition, palmitoylation of A2BAR can modulate the structure of the last transmembrane domain, which is essential for interaction with different proteins related to sorting and signaling of A2BAR.

3.6. Opioid Receptors. Opioid system plays a pivotal role in the modulation of pain behavior and antinociception. Opioid receptors are expressed in multiple CNS regions, including reward and emotion-related brain structures [122]. In addition to their well-known antinociceptive effects, opioid receptors are known to play a role in the mechanisms of drug abuse [123] and alcohol addiction [124]. There is also some evidence on involvement of opioid receptors in the mechanisms of antidepressant drug action [125]. Currently, four different opioid receptor isoforms, including $\mathrm{mu}(\mu)$, delta $(\delta)$, kappa $(\kappa)$, and opioid receptor like-1 (ORL1), have been extensively characterized at the cellular, molecular, and pharmacological levels. All four opioid receptor types couple to pertussis toxin-sensitive $\mathrm{Gi}$ protein to cause inhibition of cAMP formation [122].

The rat $\mu$-opioid receptor (MOR) has been shown to be palmitoylated, and receptor activation with morphine did not modulate the extent of receptor palmitoylation [126]. Surprisingly, mutations of the two conserved cysteine residues (i.e., Cys346 and Cys351) in the receptor's C-terminus do not affect $\left[{ }^{3} \mathrm{H}\right]$ palmitic acid incorporation, suggesting that, unlike that of the other GPCRs, palmitoylation of the MOR does not take place in its C-terminal domain. More recently, cysteine residue at position 170 was identified as a palmitoylation site of the MOR [127]. Using both experimental analysis and computational models, the authors demonstrated that receptor-bound palmitate can interact with the membrane cholesterol to facilitate receptor homodimerization and $G$ protein coupling/activation. When cholesterol metabolism or receptor palmitoylation was affected, stability of homodimers became altered, leading to the uncoupling of $\mathrm{G}$ protein. Therefore, the authors suggested that the cellular cholesterol content can represent an additional target for regulation of the receptor-mediated signaling [127]. In a more recent study, palmitoylation of the MOR was confirmed using a nonisotopic bioorthogonal click chemistry [128]. Moreover, the authors demonstrated that two PATs, zDHHC3 and zDHHC4, are capable of interacting with and palmitoylating the MOR.

The other member of opioid receptor family, the $\delta$-opioid receptor (DOR), undergoes posttranslational palmitoylation at two different cellular locations [129]. The newly synthesized DOR is constitutively palmitoylated during its transport to the cell surface, and this initial palmitoylation is needed for the efficient trafficking. After reaching the cell surface, the receptor-bound palmitate turns over rapidly in an agonist-dependent manner. It is noteworthy that the agonist-mediated turnover of DOR palmitoylation did not affect receptor- $G$ protein coupling and internalization/recycling of the receptor [129].

3.7. Cannabinoid Receptors. The endocannabinoid system consists of endogenous cannabinoids, synthetic/degradative enzymes regulating the levels of endocannabinoids, and at least two GPCRs known as the cannabinoid type 1 and type 2 receptors (CB1R and CB2R) [130]. Both CB1 and CB2 receptors couple to the $\mathrm{G}$ proteins of $\mathrm{Gi} / \mathrm{o}$ family. However, under certain conditions, coupling of this receptors to Gs and $\mathrm{Gq} / 11$ proteins was also demonstrated [131]. Endocannabinoid signaling critically regulates emotional and motivational states via activation of CB1R in the brain [132]. It is also involved in responses to stress [133], sleep-wake cycle, and mood [134]. Moreover, there are some evidence that the endocannabinoid system could modulate the functional activity of other brain neurotransmitter systems. For example, activation of $\mathrm{CB} 1$ receptor (CB1R) leads to activation of dopaminergic neurons [135].

It has been shown that endogenous CB1R in the rat brain undergoes palmitoylation and that mutation of C-terminal Cys415 residue prevents receptor palmitoylation [136]. It is 
noteworthy that recruitment of the CB1R to the plasma membrane as well as receptor localization at lipid rafts was impaired in nonpalmitoylated mutants, indicating the role of palmitoylation in receptor trafficking and localization. In addition, nonpalmitoylated CB1R significantly reduced receptor association with $\mathrm{G} \alpha \mathrm{i}$-subunit, demonstrating that palmitoylation may be responsible for the functional transmission of the agonist-induced conformational changes from receptors to the G protein [7]. Similar to that of the MOR, palmitoylation of the CB1R seems to be involved in the modulation of the conformational state of helix 8 and interactions of the CB1R with cholesterol and caveolin 1 [6]. These combined results suggest that via interaction with cholesterol, palmitoylation of the CB1R may tune receptor interaction with $\mathrm{G}$ proteins and thus act as a targeting signal for its functional regulation.

3.8. Muscarinic Acetylcholine Receptors. Muscarinic acetylcholine (ACh) receptors belong to the GPCR family and consist of five distinct receptor subtypes (M1 to M5). All five muscarinic receptor subtypes are expressed in the brain, where they activate a multitude of signaling pathways modulating synaptic plasticity, neuronal excitability, and feedback regulation of ACh release [137]. Central muscarinic receptors are also involved in higher cognitive processes such as learning and memory [138]. The brain M2 ACh receptor is known to contribute to impaired cognitive function, including a deficit in behavioral flexibility, working memory, and hippocampal plasticity $[139,140]$. M1 receptors are most abundant in the neocortex, hippocampus, and neostriatum; M4 receptors are highly expressed in the neostriatum; and M5 receptors are localized on the projection neurons of substantia nigra, pars compacta, and the hippocampus. While M2 receptors are distributed throughout the whole brain, levels of M3 receptors are relatively low [138].

All five muscarinic ACh receptor subtypes contain a conserved cysteine residue within the receptor's C-terminus in the homologous position. Mutation of the Cys457 in M2 receptor was shown to have a little effect on receptormediated AC inhibition [141]. Similarly, mutation of the Cterminal cysteine residue in M1 receptor did not affect the ligand binding or agonist-mediated phosphatidylinositol turnover [142]. Unfortunately, the authors of the abovementioned studies did not provide experimental evidence for palmitoylation of M1 and M2 receptors. Such analysis was carried out by Hayashi and Haga, who reported that M2 receptor is metabolically palmitoylated at Cys457 [143]. For the functional analysis, nonpalmitoylated receptor mutants were purified and reconstituted together with $G$ proteins into phospholipid vesicles. These experiments revealed that disruption of $\mathrm{M} 2$ receptor palmitoylation failed to affect receptor interaction with $\mathrm{Gi} / \mathrm{o}$ proteins, whereas $\mathrm{Gi}_{2}$-mediated signaling was reduced in mutant receptors. These results suggest that although the M2 receptor palmitoylation is not required for $G$ protein coupling, it can enhance the ability of the receptors to interact with $\mathrm{G}$ proteins.

3.9. Neuropeptide Y Receptors. Although the functional role of neuropeptide Y (NPY) is investigated to significantly lower extent as that for the brain serotonin, dopamine or noradrenaline, it is known that this neuropeptide could regulate levels of monoamines and corticosterone [144]. Neuropeptide $\mathrm{Y}$ acts through the specific NPY receptors $\left(\mathrm{Y}_{1}, \mathrm{Y}_{2}, \mathrm{Y}_{4}\right.$, and $Y_{5}$ ), which mediate various physiological functions and are involved in several human diseases, such as obesity, hypertension, epilepsy, metabolic disorders, and cancer [145]. Moreover, there are some data on the role of neuropeptide $\mathrm{Y}$ in the mechanisms of depression [146, 147], suggesting a possible cross-talk between this neuropeptide and the brain 5-HT system. Activation of NPY receptors leads to the inhibition of $\mathrm{AC}$ as well as to modulation of $\mathrm{Ca}^{2+}$ and $\mathrm{K}^{+}$channels [148].

Until now, palmitoylation was experimentally confirmed only for the $\mathrm{Y}_{1}$ receptor [149]. By site-directed mutagenesis, C-terminal Cys337 was identified as a single palmitoylation site on the $\mathrm{Y}_{1}$ receptor. While replacement of this cysteine by alanine or serine did not influence the high-affinity binding sites of agonists and antagonists, acylation-deficient receptor was unable to couple with corresponding $\mathrm{G}$ protein. Moreover, palmitoylation influenced receptor desensitization [149]. In general, results of this study suggest that the endogenous regulation of $\mathrm{Y}_{1}$ receptor palmitoylation may be a significant mechanism for control of balance between $\mathrm{G}$ protein activation and receptor desensitization.

3.10. Melatonin Receptors. The hormone melatonin secreted during darkness from pineal gland provides a circadian signal to the organism in vertebrates $[150,151]$. Besides its circadian regulatory functions, melatonin is involved in a variety of physiological responses including vasoactive, visual, and neuro-immunological properties, and it also possesses neuroprotective effects [152, 153]. Melatonin is implicated in a variety of diseases, including cancer and Alzheimer's disease [154]. Effects of melatonin are mediated via two specific GPCRs: MT1 and MT2 [155]. In the single study on melatonin receptor palmitoylation, Sethi and coauthors suggested that both M1 and MT2 receptors can be palmitoylated on conserved C-terminal cysteine residues Cys7.72 and Cys7.77, respectively [156]. Mutation of these putative palmitoylation sites blocked receptormediated signaling toward CAMP inhibition in each of the melatonin receptor subtypes without affecting agonist binding and agonist-induced receptor internalization [156].

\section{Palmitoylation of Ligand-Gated Ion Channels (LICs)}

4.1. Glutamate Receptors. Whereas palmitoylation of GPCRs was systematically investigated starting from the late 1980s, information on palmitoylation of neuronal LICs is much less abundant. One exception is the palmitoylation analysis of ionotropic glutamate receptors (i.e., AMPARs, NMDARs, and kainate), which all are known to undergo palmitoylation.

Glutamate is the major excitatory neurotransmitter in the mammalian CNS, which operates through activation of both metabotropic and ionotropic receptors. The ionotropic glutamate receptors (GluRs) are classified into several groups, including AMPA, NMDA, kainate, and delta receptors 
[157, 158], with AMPA and NMDA receptors representing more functionally important classes. These receptors play a crucial role in synaptic plasticity, synaptogenesis, and excitotoxicity [159]. They are also involved in a wide range of pathological behaviors, such as drug addiction [160], alcohol abuse [161, 162], anxiety [163], fear-related behavior [164], and epilepsy [165], as well as in mechanisms underlying development of schizophrenia [166]. In addition, these receptors are involved in the regulation of pain sensation [167].

4.1.1. Palmitoylation of AMPA Receptors. AMPA receptors (AMPARs) are mainly responsible for the fast excitatory transmission at central synapses. These receptors are constantly internalized, recycled, and inserted in the synapses, and such dynamic trafficking represents a main molecular mechanism for regulation of synaptic strength and synaptic plasticity $[168,169]$. AMPA receptors consist of four subunits (GluA1-GluA4) containing short cytoplasmic tails critical for regulation of their trafficking. All four AMPAR subunits possess two conserved C-terminal cysteine residues. One of them is located in the second transmembrane domain (TMD2) of the receptor, whereas the other one resides in the C-terminal region. Both cysteines can be palmitoylated in cultured neurons as well as receptors endogenously expressed in the forebrain $[4,170]$. Palmitoylation of all four AMPAR subunits was also confirmed in the nucleus accumbens (NAc) of adult rats [9]. A later study revealed that cocaine can regulate trafficking of the receptor in NAc neurons and control the response to the psychoactive drug in vivo via selective palmitoylation of AMPAR subunits [9]. In combination with an earlier report on glutamatedependent AMPA receptor depalmitoylation [170], these results suggest that palmitoylation of AMPARs takes place in multiple brain regions and can be dynamically regulated by extracellular signals.

It is noteworthy that palmitoylation of cysteines localized in TMD and in C-terminal receptor domains seems to have different functions. Palmitoylation of cysteine residue within the TMD2 caused receptor trapping in the Golgi apparatus, suggesting that palmitoylation of this cysteine is involved in the quality-control process during the receptor trafficking. A Golgi apparatus-specific protein with a DHHC zinc finger domain (GODZ) was reported to have a PAT activity for the AMPAR [170]. In the same study, GODZ- (DHHC3-) mediated palmitoylation of TMD2 cysteine was reported to disrupt the interaction of receptors with $4.1 \mathrm{~N}$, a synapseenriched cytoskeletal protein that stabilizes surface AMPAR expression and enhances susceptibility to agonist-induced internalization. Depalmitoylation of this cysteine increases the receptor affinity for $4.1 \mathrm{~N}$ and stabilizes the receptor on surface membrane [170]. Although the role of GODZ in AMPAR palmitoylation was confirmed by the overexpression of this DHHC as well as by introduction of the dominant negative mutation, it is still not clear whether the GODZ represents a main PAT for the endogenously expressed AMPARs. Indeed, a recent study by Fang and coauthors demonstrated that knock-down of GODZ reduces GABAmediated but not glutamatergic transmission [171].
More recent studies revealed that palmitoylation of GluA1 subunit requires its dynamic anterograde transport from the ER to the Golgi apparatus, while GluA2 subunits are palmitoylated by the ER-resided DHHC2 [172]. Since the majority of palmitoylated GluA2 subunits were not associated with GluA1 subunits, prevention of palmitoylation resulted in a loss of mature GluA2 subunit without affecting GluA1. In addition, pharmacological inhibition of neuronal activity increased the pool of palmitoylated GluA2, without affecting the palmitoylation levels of GluA1 [172].

4.1.2. Palmitoylation of NMDA Receptors. NMDA receptors are heteromeric complexes composed of the obligatory NR1 subunit in combination with NR2A or NR2B, representing the major NR2 subunits in forebrain [173-175]. Unlike the majority of GPCRs, which are palmitoylated on one or two conserved cysteine residues within the C-terminal domain, palmitoylation of NMDARs takes place at two distinct cysteine clusters within the long intracellular C-terminal domain of GluN2A and GluN2B receptor subunits $[4,176]$. The first cluster is proximal to the membrane (GluN2A: C848, C853, and C870; GluN2B: C849, C854, and C871). The second cluster resides in the middle of the C-terminus (GluN2A: C1214, C1217, C1236, and C1239; GluN2B: C1215, C1218, C1239, C1242, and C1245). Similar to palmitoylation of AMPARs, NMDAR palmitoylation can be regulated by neuronal activity, although responsible PATs are not yet identified. As with AMPARs, functional consequences of palmitoylation of each cluster within the NMDARs differ markedly. Palmitoylation of the first cysteine cluster on a membrane-proximal region leads to stabilizing the NMDARs at the cell surface [176]. This can be mediated by the palmitoylation-dependent increase in tyrosine phosphorylation of NR2A and NR2B via Fyn-dependent Src protein tyrosine kinase (PTK). At the molecular level, palmitoylation of Cys cluster I may, via DHHC3, modulate conformation of the NR2B C-terminus, facilitating the accessibility and/or interaction of Src-family PTKs to their substrate [176]. In addition, palmitoylation of this cluster regulates constitutive NMDA receptor internalization in developing neurons. Palmitoylation of the second cluster leads to accumulation of both NR2A- and NR2Bcontaining receptors in the Golgi apparatus, the effect quite similar to that obtained for the AMPARs. More recently, functional synaptic expression of NMDARs containing mutations of cysteine clusters was assessed by Mattison and coworkers [177]. This study demonstrated that mutation of cysteine residues within the membrane-proximal cluster causes the decrease in the synaptic expression of NMDARs mediated by enhanced receptor internalization. In contrast, mutation of the cysteines located in the middle part of the GluN2A and GluN2B C-terminus failed to alter the synaptic pool of NMDA receptors [177]. These combined results point out palmitoylation as an additional fine-tuning regulator of NMDAR trafficking

4.1.3. Palmitoylation of Kainate Receptors. Ionotropic kainite glutamate receptor GluR6 was the first ionotropic receptor shown to be palmitoylated [178]. Two cysteine residues (C827 and C840) in the putative intracellular C-terminal 
domain of the receptor were identified as palmitoylation sites. Sequence alignment performed in this study revealed that C827 of the GluR6 is conserved in all of the kainate receptors except GluK5, whereas C840 is conserved only in the mammalian kainate receptor subtypes [178]. While the current properties of the double mutant were not changed in comparison to those of the wild-type receptors, nonpalmitoylated receptors undergo stronger PKC-mediated phosphorylation. More recently, palmitoylation of the GluK2 kainate receptor subunit has been shown to promote $4.1 \mathrm{~N}$ association, whereas PKC phosphorylation antagonizes this interaction [179]. Together with the result obtained for the AMPAR palmitoylation, these data suggest that palmitoylation of AMPA and kainite receptors differentially regulates their insertion and stabilization at the cell surface. More importantly, modulation of their association with $4.1 \mathrm{~N}$ by palmitoylation and phosphorylation might represent a central mechanism for distinct functions of these receptors in the brain.

\subsection{Gamma-Aminobutyric Acid (GABAA) Receptors.} Gamma-aminobutyric acid (GABA) receptors belong to the "Cys-loop" superfamily of ligand-gated ion channels that includes nicotinic ACh receptors (see below), glycine, and serotonin $\left(5-\mathrm{HT}_{3}\right)$ receptors. GABA type A (GABAA) receptors are the major inhibitory neurotransmitter receptors in mammalian brain. These receptors are pentameric proteins composed of different subunits surrounding a central chloride ion-selective channel gated by GABA. Although many different GABAA receptor isoforms might exist, the major adult brain isoform consists of $\alpha 1, \beta 2$, and $\gamma 2$ subunits [180]. GABAA receptors are involved in various kinds of behavioral regulation, including sexual behavior [181], anxiety $[182,183]$, fear extinction learning [184], and object recognition memory [185]. These receptors also represent important pharmacological targets for treatment of several disorders, including epilepsy, anxiety, and alcoholism [186].

The GABAA receptor $\gamma 2$ subunit is palmitoylated on unique cysteine residues localized within a major intracellular domain [187]. Functional analysis showed that suppression of $\gamma 2$ subunit palmitoylation is critically involved in the synaptic clustering as well as in the regulation of the expression levels of GABAA receptors at the cell surface of cultured hippocampal neurons. Palmitoylation can also regulate trafficking and postsynaptic accumulation of GABAA receptors [171, 187]. The Golgi-resided palmitoyl acyltransferase DHHC3 (GODZ) was identified as a PAT responsible for the GABAA receptor $\gamma 2$ subunit palmitoylation in a heterologous system and in neurons [171, 187, 188]. Combined results of these studies also demonstrated that GODZ plays an important role in an assembly and functional regulation of GABAergic inhibitory synapses. In the later study, the significant role of GODZ in the palmitoylation of GABA receptors was confirmed by creating DHHC3 knock-out mice [189].

4.3. Nicotinic Acetylcholine Receptors. As GABAA receptors, nicotinic ACh receptors (nAChRs) belong to the "Cysloop" superfamily of LICs. Mammalian nAChRs contain five subunits divided into the alpha $(\alpha 2-\alpha 7, \alpha 9$, and $\alpha 10)$ and beta $(\beta 2-\beta 4)$ subfamilies, which assemble into both heteromeric and homomeric pentamers [190]. Thus there are a lot of subunit combinations leading to many different $\mathrm{nAChR}$ subtypes with various expression patterns, diverse functional properties, and differing pharmacological characteristics [191]. The nAChRs mediate excitatory neurotransmission at the neuromuscular junction, and at defined synapses in the brain, where they are often involved in the modulation of neurotransmitter release [192]. The cell surface expression of nAChRs is known to be modified during nicotine dependence and multiple disorders of the nervous system $[193,194]$.

Neuronal $\alpha 4, \beta 2$, and $\alpha 7 \mathrm{nAChR}$ subunits have been found to be palmitoylated $[195,196]$. Suppression of $\alpha 4 / \beta 2$ and homomeric $\alpha 7 \mathrm{nAChR}$ palmitoylation with bromopalmitate leads to the drastic reduction of the ligand binding, suggesting that palmitoylation might be directly involved in the formation of the ligand binding site during $\mathrm{nAChR}$ assembly in the ER [195]. Cysteine 273 in the cytoplasmic loop between transmembrane domains 1 and 2 (M1-M2) of the $\alpha 4 \mathrm{nAChR}$ was identified as a putative palmitoylation site [197]. Replacement of this cysteine by serine resulted in a nonpalmitoylated $\mathrm{nAChR}$ mutant and led to increased surface expression of receptor accompanied by decrease in the total expression. It is noteworthy that the functional activity of nonpalmitoylated $\alpha 4 \mathrm{nAChR}$ was not affected. Thus, palmitoylation of the $\alpha 4 \mathrm{nAChR}$ may be critically involved in the regulation of total and cell surface receptor expression.

4.4. $P 2 X 7$ Adenosine Receptors. The $\mathrm{P} 2 \mathrm{X} 7$ receptor is a trimeric ion channel gated by the extracellular ATP. This receptor is expressed in different tissues, including CNS. The P2X7 receptor received particular attention as a potential drug target because of its possible involvement in multiple neurological disorders, such as stroke, epilepsy, neuropathic pain, multiple sclerosis, and Alzheimer's disease [198]. In addition, recent studies demonstrated that P2X7Rs can be involved in the regulation of the pathophysiology of psychiatric disorders, including mood disorders and depression [199].

It has been shown that P2X7R is palmitoylated and that palmitoylation is responsible for association of receptor with lipid rafts at the plasma membrane [200]. The P2X7R contains 16 conserved cysteines within its intracellular domain. While cysteine residues Cys4, Cys5, Cys363, and Cys388 are not modified by palmitoylation, two separate regions of the C-terminal domain are important for P2X7R palmitoylation. The juxtamembrane cysteines in positions 371,373 , and 374 together with Cys477, 479, 482, 498, 499, 506, 572, and 573 were all implicated in palmitoylation. Functionally, palmitoylation is required for P2X7R maturation and exit from the ER, indicating that palmitoylation may play a role in the macromolecular organization of this receptor [200].

\section{Conclusion}

Data on the functional roles of palmitoylation summarized in the current review demonstrate that palmitoylation could be critically involved in the regulation of the neurotransmitter receptor's functions (Table 1). For GPCRs, these 
include binding of agonists/antagonists, targeting to the lipid microdomains, $G$ protein coupling, trafficking, desensitization/internalization, sequestration, and phosphorylation (Table 1). One central function of palmitoylation of LICs is regulation of receptor trafficking. In addition, palmitoylation of ionotropic receptors can modulate a ligand binding, phosphorylation, internalization, protein/protein interaction, and synaptic clustering (Table 1). All these processes are critically implicated in the regulation of the GPCRs and LICs functional activities, although the specific role of palmitoylation differs depending on the particular receptor. Multiple findings also show that receptor palmitoylation plays differing functional roles at different receptors, suggesting that there is no common function applicable to all neurotransmitter receptors. Therefore, an analysis of the functions of palmitoylation is necessary for each individual receptor in order to understand its signaling mechanism.

Taken together, palmitoylation of neurotransmitter receptors is critically implicated in a control of a variety of important cellular processes, such as signal transduction and synaptic clustering $[10,11,171,187]$. More importantly, pathological alterations in palmitoylation are often accompanied by severe neuronal disorders, such as Alzheimer's and Huntington's disease, schizophrenia, and mental retardation $[18,201]$. This implies the importance of the receptor palmitoylation as a potential therapeutic target for the treatment of multiple neuronal diseases.

\section{Conflicts of Interest}

The authors declare that there are no conflicts of interest regarding the publication of this paper.

\section{Acknowledgments}

The study was supported by the basic research project grant no. 0324-2018-0016, Russian Foundation for Basic Research Grant no. 16-54-12016, and the Deutsche Forschungsgemeinschaft through the Grant PO 732 and the Excellent Cluster REBIRTH to Evgeni Ponimaskin.

\section{References}

[1] I. J. Uings and S. N. Farrow, "Cell receptors and cell signalling," Molecular Pathology, vol. 53, no. 6, pp. 295-299, 2000.

[2] M. M. Zhang and H. C. Hang, "Protein S-palmitoylation in cellular differentiation," Biochemical Society Transactions, vol. 45, no. 1, pp. 275-285, 2017.

[3] W. C. Probst, L. A. Snyder, D. I. Schuster, J. Brosius, and S. C. Sealfon, "Sequence alignment of the G-protein coupled receptor superfamily," DNA and Cell Biology, vol. 11, no. 1, pp. 1-20, 1992.

[4] R. Kang, J. Wan, P. Arstikaitis et al., "Neural palmitoylproteomics reveals dynamic synaptic palmitoylation," Nature, vol. 456, no. 7224, pp. 904-909, 2008.

[5] M. O. Collins, K. T. Woodley, and J. S. Choudhary, "Global, site-specific analysis of neuronal protein S-acylation," Scientific Reports, vol. 7, no. 1, p. 4683, 2017.

[6] S. Oddi, T. M. Stepniewski, A. Totaro et al., "Palmitoylation of cysteine 415 of $\mathrm{CB}_{1}$ receptor affects ligand-stimulated internalization and selective interaction with membrane cholesterol and caveolin 1," Biochimica et Biophysica Acta (BBA) - Molecular and Cell Biology of Lipids, vol. 1862, no. 5, pp. 523-532, 2017.

[7] S. Oddi, A. Totaro, L. Scipioni et al., "Role of palmitoylation of cysteine 415 in functional coupling $\mathrm{CB}_{1}$ receptor to $\mathrm{G} \alpha_{\mathrm{i} 2}$ protein," Biotechnology and Applied Biochemistry, vol. 65, no. 1, pp. 16-20, 2018.

[8] N. Adachi, D. T. Hess, P. McLaughlin, and J. S. Stamler, "S-Palmitoylation of a novel site in the $\beta_{2}$-adrenergic receptor associated with a novel intracellular itinerary," Journal of Biological Chemistry, vol. 291, no. 38, pp. 20232-20246, 2016.

[9] D. K. Van Dolah, L.-M. Mao, C. Shaffer et al., "Reversible palmitoylation regulates surface stability of AMPA receptors in the nucleus accumbens in response to cocaine in vivo," Biological Psychiatry, vol. 69, no. 11, pp. 10351042, 2011.

[10] T. P. Loisel, L. Adam, T. E. Hebert, and M. Bouvier, “Agonist stimulation increases the turnover rate of $\beta_{2}$ AR-bound palmitate and promotes receptor depalmitoylation," Biochemistry, vol. 35, no. 49, pp. 15923-15932, 1996.

[11] B. Mouillac, M. Caron, H. Bonin, M. Dennis, and M. Bouvier, "Agonist-modulated palmitoylation of beta 2-adrenergic receptor in Sf9 cells," Journal of Biological Chemistry, vol. 267, no. 30, pp. 21733-21737, 1992.

[12] A. F. Roth, J. Wan, A. O. Bailey et al., "Global analysis of protein palmitoylation in yeast," Cell, vol. 125, no. 5, pp. 1003-1013, 2006.

[13] M. E. Linder and R. J. Deschenes, "New insights into the mechanisms of protein palmitoylation," Biochemistry, vol. 42, no. 15, pp. 4311-4320, 2003.

[14] Y. Fukata and M. Fukata, "Protein palmitoylation in neuronal development and synaptic plasticity," Nature Reviews Neuroscience, vol. 11, no. 3, pp. 161-175, 2010.

[15] S. L. Planey and D. A. Zacharias, "Palmitoyl acyltransferases, their substrates, and novel assays to connect them (review)," Molecular Membrane Biology, vol. 26, no. 1-2, pp. 14-31, 2009.

[16] C. D. Gottlieb and M. E. Linder, "Structure and function of DHHC protein S-acyltransferases," Biochemical Society Transactions, vol. 45, no. 4, pp. 923-928, 2017.

[17] Y. Ohno, A. Kihara, T. Sano, and Y. Igarashi, "Intracellular localization and tissue-specific distribution of human and yeast DHHC cysteine-rich domain-containing proteins," Biochimica et Biophysica Acta (BBA) - Molecular and Cell Biology of Lipids, vol. 1761, no. 4, pp. 474-483, 2006.

[18] E. Cho and M. Park, "Palmitoylation in Alzheimer's disease and other neurodegenerative diseases," Pharmacological Research, vol. 111, pp. 133-151, 2016.

[19] J. Greaves and L. H. Chamberlain, "S-Acylation by the DHHC protein family," Biochemical Society Transactions, vol. 38, no. 2, pp. 522-524, 2010.

[20] M. Fukata, Y. Fukata, H. Adesnik, R. A. Nicoll, and D. S. Bredt, "Identification of PSD-95 palmitoylating enzymes," Neuron, vol. 44, no. 6, pp. 987-996, 2004.

[21] E. Ponimaskin, G. Dityateva, M. O. Ruonala et al., "Fibroblast growth factor-regulated palmitoylation of the neural cell adhesion molecule determines neuronal morphogenesis," The Journal of Neuroscience, vol. 28, no. 36, pp. 8897-8907, 2008. 
[22] P. M.-J. Lievens, T. Kuznetsova, G. Kochlamazashvili et al., "ZDHHC3 tyrosine phosphorylation regulates neural cell adhesion molecule Palmitoylation," Molecular and Cellular Biology, vol. 36, no. 17, pp. 2208-2225, 2016.

[23] M. E. Linder and B. C. Jennings, "Mechanism and function of DHHC S-acyltransferases," Biochemical Society Transactions, vol. 41, no. 1, pp. 29-34, 2013.

[24] K. Huang, A. Yanai, R. Kang et al., "Huntingtin-interacting protein HIP14 is a palmitoyl transferase involved in palmitoylation and trafficking of multiple neuronal proteins," Neuron, vol. 44, no. 6, pp. 977-986, 2004.

[25] R. R. Singaraja, S. Hadano, M. Metzler et al., "HIP14, a novel ankyrin domain-containing protein, links huntingtin to intracellular trafficking and endocytosis," Human Molecular Genetics, vol. 11, no. 23, pp. 2815-2828, 2002.

[26] G. J. Fredericks, F. W. Hoffmann, A. H. Rose et al., "Stable expression and function of the inositol 1,4,5-triphosphate receptor requires palmitoylation by a DHHC6/selenoprotein K complex," Proceedings of the National Academy of Sciences of the United States of America, vol. 111, no. 46, pp. 1647816483, 2014.

[27] Y. Li, J. Hu, K. Höfer et al., "DHHC5 interacts with PDZ domain 3 of post-synaptic density-95 (PSD-95) protein and plays a role in learning and memory," Journal of Biological Chemistry, vol. 285, no. 17, pp. 13022-13031, 2010.

[28] C. Salaun, L. Ritchie, J. Greaves, T. J. Bushell, and L. H. Chamberlain, "The C-terminal domain of zDHHC2 contains distinct sorting signals that regulate intracellular localisation in neurons and neuroendocrine cells," Molecular and Cellular Neuroscience, vol. 85, pp. 235-246, 2017.

[29] R. Verardi, J. S. Kim, R. Ghirlando, and A. Banerjee, "Structural basis for substrate recognition by the ankyrin repeat domain of human DHHC17 palmitoyltransferase," Structure, vol. 25, no. 9, pp. 1337-1347.e6, 2017.

[30] J. Greaves, K. R. Munro, S. C. Davidson et al., "Molecular basis of fatty acid selectivity in the zDHHC family of Sacyltransferases revealed by click chemistry," Proceedings of the National Academy of Sciences of the United States of America, vol. 114, no. 8, pp. E1365-E1374, 2017.

[31] L. Muszbek and M. Laposata, "Covalent modification of proteins by arachidonate and eicosapentaenoate in platelets," Journal of Biological Chemistry, vol. 268, no. 24, pp. 1824318248, 1993.

[32] J. P. Wilson, A. S. Raghavan, Y.-Y. Yang, G. Charron, and H. C. Hang, "Proteomic analysis of fatty-acylated proteins in mammalian cells with chemical reporters reveals S-acylation of histone H3 variants," Molecular \& Cellular Proteomics, vol. 10, no. 3, article M110.001198, 2011.

[33] D. T. S. Lin and E. Conibear, "Enzymatic protein depalmitoylation by acyl protein thioesterases," Biochemical Society Transactions, vol. 43, no. 2, pp. 193-198, 2015.

[34] D. T. S. Lin and E. Conibear, "ABHD17 proteins are novel protein depalmitoylases that regulate N-Ras palmitate turnover and subcellular localization," eLife, vol. 4, 2015.

[35] N. Yokoi, Y. Fukata, A. Sekiya, T. Murakami, K. Kobayashi, and M. Fukata, "Identification of PSD-95 depalmitoylating enzymes," The Journal of Neuroscience, vol. 36, no. 24, pp. 6431-6444, 2016.

[36] B. Chavda, J. A. Arnott, and S. L. Planey, "Targeting protein palmitoylation: selective inhibitors and implications in disease," Expert Opinion on Drug Discovery, vol. 9, no. 9, pp. 1005-1019, 2014.

[37] T. Xia, Y. Cui, H. Shi, Z. Ma, and X. Gu, "The effect of NR2B subunit palmitoylation at the spinal level after chronic dorsal root ganglia compression in rats," Anesthesia \& Analgesia, vol. 119, no. 5, pp. 1208-1214, 2014.

[38] D. B. Bylund, D. C. Eikenberg, J. P. Hieble et al., "International Union of Pharmacology nomenclature of adrenoceptors," Pharmacological Reviews, vol. 46, no. 2, pp. 121-136, 1994.

[39] R. Gordan, J. K. Gwathmey, and L. H. Xie, "Autonomic and endocrine control of cardiovascular function," World Journal of Cardiology, vol. 7, no. 4, pp. 204-214, 2015.

[40] G. Patki, F. Atrooz, I. Alkadhi, N. Solanki, and S. Salim, "High aggression in rats is associated with elevated stress, anxietylike behavior, and altered catecholamine content in the brain," Neuroscience Letters, vol. 584, pp. 308-313, 2015.

[41] E. M. S. Snoeren, "The role of adrenoceptors in the central nervous system in male and female rat sexual behavior," European Journal of Pharmacology, vol. 753, pp. 229-245, 2015.

[42] C. Strobel, S. Hunt, R. Sullivan, J. Y. Sun, and P. Sah, "Emotional regulation of pain: the role of noradrenaline in the amygdala," Science China Life Sciences, vol. 57, no. 4, pp. 384-390, 2014.

[43] A. F. T. Arnsten, "The use of $\alpha-2 \mathrm{~A}$ adrenergic agonists for the treatment of attention-deficit/hyperactivity disorder," Expert Review of Neurotherapeutics, vol. 10, no. 10, pp. 1595-1605, 2010.

[44] J. R. McReynolds, D. F. Peña, J. M. Blacktop, and J. R. Mantsch, "Neurobiological mechanisms underlying relapse to cocaine use: contributions of CRF and noradrenergic systems and regulation by glucocorticoids," Stress, vol. 17, no. 1, pp. 22-38, 2014.

[45] C. Cottingham, C. J. Ferryman, and Q. Wang, " $\alpha_{2}$ adrenergic receptor trafficking as a therapeutic target in antidepressant drug action," Progress in Molecular Biology and Translational Science, vol. 132, pp. 207-225, 2015.

[46] A. J. Espay, P. A. LeWitt, and H. Kaufmann, "Norepinephrine deficiency in Parkinson's disease: the case for noradrenergic enhancement," Movement Disorders, vol. 29, no. 14, pp. 1710-1719, 2014.

[47] B. F. O'Dowd, M. Hnatowich, M. G. Caron, R. J. Lefkowitz, and M. Bouvier, "Palmitoylation of the human beta 2adrenergic receptor. Mutation of Cys341 in the carboxyl tail leads to an uncoupled nonpalmitoylated form of the receptor," Journal of Biological Chemistry, vol. 264, no. 13, pp. 7564-7569, 1989.

[48] M. Trester-Zedlitz, A. Burlingame, B. Kobilka, and M. von Zastrow, "Mass spectrometric analysis of agonist effects on posttranslational modifications of the $\beta-2$ adrenoceptor in mammalian cells," Biochemistry, vol. 44, no. 16, pp. 61336143, 2005.

[49] S. Moffett, B. Mouillac, H. Bonin, and M. Bouvier, "Altered phosphorylation and desensitization patterns of a human beta 2-adrenergic receptor lacking the palmitoylated Cys341," The EMBO Journal, vol. 12, no. 1, pp. 349-356, 1993.

[50] S. Moffett, L. Adam, H. Bonin, T. P. Loisel, M. Bouvier, and B. Mouillac, "Palmitoylated cysteine 341 modulates phosphorylation of the $\beta 2$-adrenergic receptor by the cAMP- 
dependent protein kinase," Journal of Biological Chemistry, vol. 271, no. 35, pp. 21490-21497, 1996.

[51] S. Moffett, G. Rousseau, M. Lagacé, and M. Bouvier, "The palmitoylation state of the $\beta_{2}$-adrenergic receptor regulates the synergistic action of cyclic AMP-dependent protein kinase and $\beta$-adrenergic receptor kinase involved in its phosphorylation and desensitization," Journal of Neurochemistry, vol. 76, no. 1, pp. 269-279, 2001.

[52] R. Liu, D. Wang, Q. Shi, Q. Fu, S. Hizon, and Y. K. Xiang, "Palmitoylation regulates intracellular trafficking of $\beta_{2}$ adrenergic receptor/arrestin/phosphodiesterase $4 \mathrm{D}$ complexes in cardiomyocytes," PLoS One, vol. 7, no. 8, article e42658, 2012.

[53] L. Adam, M. Bouvier, and T. L. Z. Jones, "Nitric oxide modulates $\beta_{2}$-adrenergic receptor palmitoylation and signaling," Journal of Biological Chemistry, vol. 274, no. 37, pp. 2633726343, 1999.

[54] M. E. Kennedy and L. E. Limbird, "Mutations of the $\alpha_{2 A^{-}}$ adrenergic receptor that eliminate detectable palmitoylation do not perturb receptor-G-protein coupling," Journal of Biological Chemistry, vol. 268, no. 11, pp. 8003-8011, 1993.

[55] M. E. Kennedy and L. E. Limbird, "Palmitoylation of the $\alpha_{2 A^{-}}$ adrenergic receptor. Analysis of the sequence requirements for and the dynamic properties of alpha 2A-adrenergic receptor palmitoylation," Journal of Biological Chemistry, vol. 269, no. 50, pp. 31915-31922, 1994.

[56] E. Barclay, M. O'Reilly, and G. Milligan, "Activation of an $\alpha_{2 \mathrm{~A}}$-adrenoceptor- $\mathrm{G} \alpha_{\mathrm{ol}}$ fusion protein dynamically regulates the palmitoylation status of the $G$ protein but not of the receptor," Biochemical Journal, vol. 385, no. 1, pp. 197-206, 2005.

[57] M. G. Eason, M. T. Jacinto, C. T. Theiss, and S. B. Liggett, "The palmitoylated cysteine of the cytoplasmic tail of alpha 2A-adrenergic receptors confers subtype-specific agonistpromoted downregulation," Proceedings of the National Academy of Sciences of the United States of America, vol. 91, no. 23, pp. 11178-11182, 1994.

[58] E. P. Marin, L. Jozsef, A. Di Lorenzo et al., "The protein acyl transferase ZDHHC21 modulates $\alpha 1$ adrenergic receptor function and regulates hemodynamics," Arteriosclerosis, Thrombosis, and Vascular Biology, vol. 36, no. 2, pp. 370379, 2016.

[59] I. Nalepa, G. Kreiner, A. Bielawski, K. Rafa-Zabłocka, and A. Roman, " $\alpha_{1}$-Adrenergic receptor subtypes in the central nervous system: insights from genetically engineered mouse models," Pharmacological Reports, vol. 65, no. 6, pp. 14891497, 2013.

[60] N. K. Popova and V. S. Naumenko, " $5-\mathrm{HT}_{1 \mathrm{~A}}$ receptor as a key player in the brain 5-HT system," Reviews in the Neurosciences, vol. 24, no. 2, pp. 191-204, 2013.

[61] S. F. de Boer, M. Lesourd, E. Mocaer, and J. M. Koolhaas, "Selective antiaggressive effects of alnespirone in residentintruder test are mediated via 5-hydroxytryptamine ${ }_{1 \mathrm{~A}}$ receptors: a comparative pharmacological study with 8-hydroxy-2dipropylaminotetralin, ipsapirone, buspirone, eltoprazine, and WAY-100635," The Journal of Pharmacology and Experimental Therapeutics, vol. 288, no. 3, pp. 1125-1133, 1999.

[62] L. K. Heisler, H. M. Chu, T. J. Brennan et al., "Elevated anxiety and antidepressant-like responses in serotonin $5-\mathrm{HT}_{1 \mathrm{~A}}$ receptor mutant mice," Proceedings of the National Academy of Sciences of the United States of America, vol. 95, no. 25, pp. 15049-15054, 1998.
[63] P. R. Albert, B. Le Francois, and A. M. Millar, "Transcriptional dysregulation of 5-HT1A autoreceptors in mental illness," Molecular Brain, vol. 4, no. 1, p. 21, 2011.

[64] M. Maes and H. Y. Meltzer, "The serotonin hypothesis of major depression," in Psychopharmacology: The Fourth Generation of Progress, E. E. Bloom and N. N. Kupfer, Eds., pp. 933-944, Raven Press, New York, NY, USA, 1995.

[65] C. A. Stockmeier, L. A. Shapiro, G. E. Dilley, T. N. Kolli, L. Friedman, and G. Rajkowska, "Increase in serotonin-1A autoreceptors in the midbrain of suicide victims with major depression-postmortem evidence for decreased serotonin activity," The Journal of Neuroscience, vol. 18, no. 18, pp. 7394-7401, 1998.

[66] E. Papoucheva, A. Dumuis, M. Sebben, D. W. Richter, and E. G. Ponimaskin, "The 5-hydroxytryptamine (1A) receptor is stably palmitoylated, and acylation is critical for communication of receptor with $\mathrm{G}_{\mathrm{i}}$ protein," Journal of Biological Chemistry, vol. 279, no. 5, pp. 3280-3291, 2004.

[67] U. Renner, K. Glebov, T. Lang et al., "Localization of the mouse 5-hydroxytryptamine ${ }_{1 \mathrm{~A}}$ receptor in lipid microdomains depends on its palmitoylation and is involved in receptor-mediated signaling," Molecular Pharmacology, vol. 72, no. 3, pp. 502-513, 2007.

[68] N. Gorinski and E. Ponimaskin, "Palmitoylation of serotonin receptors," Biochemical Society Transactions, vol. 41, no. 1, pp. 89-94, 2013.

[69] G. Y. Ng, S. R. George, R. L. Zastawny et al., "Human serotonin $1 \mathrm{~B}$ receptor expression in Sf9 cells: phosphorylation, palmitoylation, and adenylyl cyclase inhibition," Biochemistry, vol. 32, no. 43, pp. 11727-11733, 1993.

[70] J. Bockaert, S. Claeysen, V. Compan, and A. Dumuis, "5-HT receptors: history, molecular pharmacology and brain functions," Neuropharmacology, vol. 55, no. 6, pp. 922-931, 2008.

[71] L. Jean, B. Thomas, A. Tahiri-Alaoui, M. Shaw, and D. J. Vaux, "Heterologous amyloid seeding: revisiting the role of acetylcholinesterase in Alzheimer's disease," PLoS One, vol. 2, no. 7, article e652, 2007.

[72] E. H. Wong, G. P. Reynolds, D. W. Bonhaus, S. Hsu, and R. M. Eglen, "Characterization of $\left[{ }^{3} \mathrm{H}\right] \mathrm{GR} 113808$ binding to $5-\mathrm{HT}_{4}$ receptors in brain tissues from patients with neurodegenerative disorders," Behavioural Brain Research, vol. 73, no. 1-2, pp. 249-252, 1996.

[73] E. G. Ponimaskin, M. F. G. Schmidt, M. Heine, U. Bickmeyer, and D. W. Richter, "5-Hydroxytryptamine 4(a) receptor expressed in Sf9 cells is palmitoylated in an agonistdependent manner," Biochemical Journal, vol. 353, no. 3, pp. 627-634, 2001.

[74] E. G. Ponimaskin, M. Heine, L. Joubert et al., "The 5hydroxytryptamine (4a) receptor is palmitoylated at two different sites, and acylation is critically involved in regulation of receptor constitutive activity," Journal of Biological Chemistry, vol. 277, no. 4, pp. 2534-2546, 2002.

[75] E. Kvachnina, A. Dumuis, J. Wlodarczyk et al., "Constitutive $\mathrm{G}_{\mathrm{s}}$-mediated, but not $\mathrm{G}_{12}$-mediated, activity of the 5hydroxytryptamine $5-\mathrm{HT}_{7(\mathrm{a})}$ receptor is modulated by the palmitoylation of its C-terminal domain," Biochimica et Biophysica Acta (BBA) - Molecular Cell Research, vol. 1793, no. 11, pp. 1646-1655, 2009.

[76] M. J. Duncan, J. Short, and D. L. Wheeler, "Comparison of the effects of aging on $5-\mathrm{HT}_{7}$ and $5-\mathrm{HT}_{1 \mathrm{~A}}$ receptors in discrete regions of the circadian timing system in hamsters," Brain Research, vol. 829, no. 1-2, pp. 39-45, 1999. 
[77] T. W. Lovenberg, B. M. Baron, L. de Lecea et al., "A novel adenylyl cyclase-activating serotonin receptor (5-HT7) implicated in the regulation of mammalian circadian rhythms," Neuron, vol. 11, no. 3, pp. 449-458, 1993.

[78] P. B. Hedlund, "The $5-\mathrm{HT}_{7}$ receptor and disorders of the nervous system: an overview," Psychopharmacology, vol. 206, no. 3, pp. 345-354, 2009.

[79] E. Kvachnina, G. Liu, A. Dityatev et al., "5- $\mathrm{HT}_{7}$ receptor is coupled to $\mathrm{G} \alpha$ subunits of heterotrimeric G12-protein to regulate gene transcription and neuronal morphology," The Journal of Neuroscience, vol. 25, no. 34, pp. 7821-7830, 2005.

[80] F. Kobe, D. Guseva, T. P. Jensen et al., " $5-\mathrm{HT}_{7} \mathrm{R} / \mathrm{G}_{12}$ signaling regulates neuronal morphology and function in an agedependent manner," The Journal of Neuroscience, vol. 32, no. 9, pp. 2915-2930, 2012.

[81] N. D. Volkow, G. J. Wang, and R. D. Baler, "Reward, dopamine and the control of food intake: implications for obesity," Trends in Cognitive Sciences, vol. 15, no. 1, pp. 37-46, 2011.

[82] T. E. Foley and M. Fleshner, "Neuroplasticity of dopamine circuits after exercise: implications for central fatigue," $\mathrm{Neu}$ romolecular Medicine, vol. 10, no. 2, pp. 67-80, 2008.

[83] A. Q. Rana, Z. M. Chaudry, and P. J. Blanchet, "New and emerging treatments for symptomatic tardive dyskinesia," Drug Design, Development and Therapy, vol. 7, pp. 13291340, 2013.

[84] F. Antonelli and A. P. Strafella, "Behavioral disorders in Parkinson's disease: the role of dopamine," Parkinsonism \& Related Disorders, vol. 20, Supplement 1, pp. S10-S12, 2014.

[85] A. V. McCormick, J. M. Wheeler, C. R. Guthrie, N. F. Liachko, and B. C. Kraemer, "Dopamine D2 receptor antagonism suppresses tau aggregation and neurotoxicity," Biological Psychiatry, vol. 73, no. 5, pp. 464-471, 2013.

[86] P. S. D'Aquila, M. Collu, G. L. Gessa, and G. Serra, “The role of dopamine in the mechanism of action of antidepressant drugs," European Journal of Pharmacology, vol. 405, no. 13, pp. 365-373, 2000.

[87] J. Yao, M. Ding, J. Xing et al., "Genetic association between the dopamine D1-receptor gene and paranoid schizophrenia in a northern Han Chinese population," Neuropsychiatric Disease and Treatment, vol. 10, pp. 645-652, 2014.

[88] G. Camardese, D. Di Giuda, M. Di Nicola et al., "Imaging studies on dopamine transporter and depression: a review of literature and suggestions for future research," Journal of Psychiatric Research, vol. 51, pp. 7-18, 2014.

[89] L. Lattanzi, L. Dell'Osso, P. Cassano et al., "Pramipexole in treatment-resistant depression: a 16-week naturalistic study," Bipolar Disorders, vol. 4, no. 5, pp. 307-314, 2002.

[90] C. P. Ford, "The role of D2-autoreceptors in regulating dopamine neuron activity and transmission," Neuroscience, vol. 282, pp. 13-22, 2014.

[91] G. Y. K. Ng, B. Mouillac, S. R. George et al., "Desensitization, phosphorylation and palmitoylation of the human dopamine $\mathrm{D}_{1}$ receptor," European Journal of Pharmacology: Molecular Pharmacology, vol. 267, no. 1, pp. 7-19, 1994.

[92] H. Jin, R. Zastawny, S. R. George, and B. F. O'Dowd, "Elimination of palmitoylation sites in the human dopamine $\mathrm{D}_{1}$ receptor does not affect receptor-G protein interaction," European Journal of Pharmacology, vol. 324, no. 1, pp. 109116, 1997.

[93] H. Jin, Z. Xie, S. R. George, and B. F. O'Dowd, "Palmitoylation occurs at cysteine 347 and cysteine 351 of the dopamine
$\mathrm{D}_{1}$ receptor," European Journal of Pharmacology, vol. 386, no. 2-3, pp. 305-312, 1999.

[94] M. M. C. Kong, V. Verma, B. F. O’Dowd, and S. R. George, "The role of palmitoylation in directing dopamine D1 receptor internalization through selective endocytic routes," Biochemical and Biophysical Research Communications, vol. 405, no. 3, pp. 445-449, 2011.

[95] S. Grünewald, W. Haase, H. Reiländer, and H. Michel, “Glycosylation, palmitoylation, and localization of the human $\mathrm{D}_{2 \mathrm{~S}}$ receptor in baculovirus-infected insect cells," Biochemistry, vol. 35, no. 48, pp. 15149-15161, 1996.

[96] G. Y. Ng, B. F. O'Dowd, M. Caron, M. Dennis, M. R. Brann, and S. R. George, "Phosphorylation and palmitoylation of the human D2L dopamine receptor in Sf9 cells," Journal of Neurochemistry, vol. 63, no. 5, pp. 1589-1595, 1994.

[97] B. Ebersole, J. Petko, M. Woll et al., "Effect of C-terminal S-palmitoylation on D2 dopamine receptor trafficking and stability," PLoS One, vol. 10, no. 11, article e0140661, 2015.

[98] X. Zhang, H. T. Le, X. Zhang, M. Zheng, B.-G. Choi, and K.-M. Kim, "Palmitoylation on the carboxyl terminus tail is required for the selective regulation of dopamine $D_{2}$ versus $\mathrm{D}_{3}$ receptors," Biochimica et Biophysica Acta (BBA) - Biomembranes, vol. 1858, no. 9, pp. 2152-2162, 2016.

[99] D. I. Cho, M. Zheng, and K. M. Kim, "Current perspectives on the selective regulation of dopamine $\mathrm{D}_{2}$ and $\mathrm{D}_{3}$ receptors," Archives of Pharmacal Research, vol. 33, no. 10, pp. 15211538, 2010.

[100] X. Zhang and K. M. Kim, "Palmitoylation of the carboxylterminal tail of dopamine $\mathrm{D}_{4}$ receptor is required for surface expression, endocytosis, and signaling," Biochemical and Biophysical Research Communications, vol. 479, no. 2, pp. 398-403, 2016.

[101] T. A. Koshimizu, K. Nakamura, N. Egashira, M. Hiroyama, H. Nonoguchi, and A. Tanoue, "Vasopressin V1a and V1b receptors: from molecules to physiological systems," Physiological Reviews, vol. 92, no. 4, pp. 1813-1864, 2012.

[102] A. Barsegyan, P. Atsak, W. B. Hornberger, P. B. Jacobson, M. M. van Gaalen, and B. Roozendaal, "The vasopressin $1 \mathrm{~b}$ receptor antagonist A-988315 blocks stress effects on the retrieval of object-recognition memory," Neuropsychopharmacology, vol. 40, no. 8, pp. 1979-1989, 2015.

[103] D. S. Bayerl, J. N. Honig, and O. J. Bosch, "Vasopressin $\mathrm{V} 1 \mathrm{a}$, but not V1b, receptors within the PVN of lactating rats mediate maternal care and anxiety-related behaviour," Behavioural Brain Research, vol. 305, pp. 18-22, 2016.

[104] J. M. Zimmermann-Peruzatto, V. M. Lazzari, A. C. de Moura, S. Almeida, and M. Giovenardi, "Examining the role of vasopressin in the modulation of parental and sexual behaviors," Frontiers in Psychiatry, vol. 6, p. 130, 2015.

[105] L. J. Young and L. M. Flanagan-Cato, "Editorial comment: oxytocin, vasopressin and social behavior," Hormones and Behavior, vol. 61, no. 3, pp. 227-229, 2012.

[106] J. H. Pagani, M. Zhao, Z. Cui et al., "Role of the vasopressin $1 \mathrm{~b}$ receptor in rodent aggressive behavior and synaptic plasticity in hippocampal area CA2," Molecular Psychiatry, vol. 20, no. 4, pp. 490-499, 2015.

[107] K. Sato, T. Numata, T. Saito, Y. Ueta, and Y. Okada, "V 2 receptor-mediated autocrine role of somatodendritic release of AVP in rat vasopressin neurons under hypo-osmotic conditions," Science Signaling, vol. 4, no. 157, article ra5, 2011. 
[108] S. R. Hawtin, A. B. Tobin, S. Patel, and M. Wheatley, "Palmitoylation of the vasopressin $\mathrm{V}_{1 \mathrm{a}}$ receptor reveals different conformational requirements for signaling, agonist-induced receptor phosphorylation, and sequestration," Journal of Biological Chemistry, vol. 276, no. 41, pp. 38139-38146, 2001.

[109] R. Schüllein, U. Liebenhoff, H. Mülller, M. Birnbaumer, and W. Rosenthal, "Properties of the human arginine vasopressin V2 receptor after site-directed mutagenesis of its putative palmitoylation site," Biochemical Journal, vol. 313, no. 2, pp. 611-616, 1996.

[110] H. M. Sadeghi, G. Innamorati, M. Dagarag, and M. Birnbaumer, "Palmitoylation of the $\mathrm{V}_{2}$ vasopressin receptor," Molecular Pharmacology, vol. 52, no. 1, pp. 21-29, 1997.

[111] P. G. Charest and M. Bouvier, "Palmitoylation of the V2 vasopressin receptor carboxyl tail enhances $\beta$-arrestin recruitment leading to efficient receptor endocytosis and ERK1/2 activation," Journal of Biological Chemistry, vol. 278, no. 42, pp. 41541-41551, 2003.

[112] S. Sheth, R. Brito, D. Mukherjea, L. Rybak, and V. Ramkumar, "Adenosine receptors: expression, function and regulation," International Journal of Molecular Sciences, vol. 15, no. 12, pp. 2024-2052, 2014.

[113] L. López-Cruz, M. Carbó-Gas, M. Pardo et al., "Adenosine $\mathrm{A}_{2 \mathrm{~A}}$ receptor deletion affects social behaviors and anxiety in mice: involvement of anterior cingulate cortex and amygdala," Behavioural Brain Research, vol. 321, pp. 8-17, 2017.

[114] L. Caetano, H. Pinheiro, P. Patrício et al., "Adenosine $A_{2 A}$ receptor regulation of microglia morphological remodelinggender bias in physiology and in a model of chronic anxiety," Molecular Psychiatry, vol. 22, no. 7, pp. 1035-1043, 2016.

[115] P. Singer, C. J. Wei, J. F. Chen, D. Boison, and B. K. Yee, "Deletion of striatal adenosine $\mathrm{A}_{2 \mathrm{~A}}$ receptor spares latent inhibition and prepulse inhibition but impairs active avoidance learning," Behavioural Brain Research, vol. 242, pp. 54-61, 2013.

[116] M. P. Kaster, N. J. Machado, H. B. Silva et al., "Caffeine acts through neuronal adenosine $\mathrm{A}_{2 \mathrm{~A}}$ receptors to prevent mood and memory dysfunction triggered by chronic stress," Proceedings of the National Academy of Sciences of the United States of America, vol. 112, no. 25, pp. 78337838, 2015.

[117] M. Moscoso-Castro, I. Gracia-Rubio, F. Ciruela, and O. Valverde, "Genetic blockade of adenosine $\mathrm{A}_{2 \mathrm{~A}}$ receptors induces cognitive impairments and anatomical changes related to psychotic symptoms in mice," European Neuropsychopharmacology, vol. 26, no. 7, pp. 1227-1240, 2016.

[118] Z. Gao, Y. Ni, G. Szabo, and J. Linden, "Palmitoylation of the recombinant human A1 adenosine receptor: enhanced proteolysis of palmitoylation-deficient mutant receptors," Biochemical Journal, vol. 342, no. 2, pp. 387-395, 1999.

[119] G. Ferguson, K. R. Watterson, and T. M. Palmer, "Subtypespecific regulation of receptor internalization and recycling by the carboxyl-terminal domains of the human $\mathrm{A}_{1}$ and rat $\mathrm{A}_{3}$ adenosine receptors: consequences for agonist-stimulated translocation of Arrestin3," Biochemistry, vol. 41, no. 50, pp. 14748-14761, 2002.

[120] T. M. Palmer and G. L. Stiles, "Identification of threonine residues controlling the agonist-dependent phosphorylation and desensitization of the rat A(3) adenosine receptor," Molecular Pharmacology, vol. 57, no. 3, pp. 539-545, 2000.

[121] M. Mansourian, A. Madadkar-Sobhani, K. Mahnam, A. Fassihi, and L. Saghaie, "Characterization of adenosine receptor in its native environment: insights from molecular dynamics simulations of palmitoylated/glycosylated, membrane-integrated human $\mathrm{A}(2 \mathrm{~B})$ adenosine receptor," Journal of Molecular Modeling, vol. 18, no. 9, pp. 43094324, 2012.

[122] R. Al-Hasani and M. R. Bruchas, "Molecular mechanisms of opioid receptor-dependent signaling and behavior," Anesthesiology, vol. 115, no. 6, pp. 1363-1381, 2011.

[123] X. F. Wang, E. Barbier, Y. T. Chiu et al., “T394A mutation at the $\mu$ opioid receptor blocks opioid tolerance and increases vulnerability to heroin self-administration in mice," The Journal of Neuroscience, vol. 36, no. 40, pp. 10392-10403, 2016.

[124] D. Alongkronrusmee, T. Chiang, and R. M. van Rijn, "Delta opioid pharmacology in relation to alcohol behaviors," in Handbook of Experimental Pharmacology, pp. 1-27, Springer, Berlin, Heidelberg, 2016.

[125] S. A. Robinson, R. L. Erickson, C. A. Browne, and I. Lucki, "A role for the mu opioid receptor in the antidepressant effects of buprenorphine," Behavioural Brain Research, vol. 319, pp. 96-103, 2017.

[126] C. Chen, V. Shahabi, W. Xu, and L. Y. Liu-Chen, "Palmitoylation of the rat $\mu$ opioid receptor," FEBS Letters, vol. 441, no. 1, pp. 148-152, 1998.

[127] H. Zheng, E. A. Pearsall, D. P. Hurst et al., "Palmitoylation and membrane cholesterol stabilize $\mu$-opioid receptor homodimerization and G protein coupling," BMC Cell Biology, vol. 13, no. 1, p. 6, 2012.

[128] B. Ebersole, J. Petko, and R. Levenson, "Bioorthogonal click chemistry to assay mu-opioid receptor palmitoylation using 15-hexadecynoic acid and immunoprecipitation," Analytical Biochemistry, vol. 451, pp. 25-27, 2014.

[129] U. E. Petäjä-Repo, M. Hogue, T. T. Leskelä, P. M. H. Markkanen, J. T. Tuusa, and M. Bouvier, "Distinct subcellular localization for constitutive and agonist-modulated palmitoylation of the human $\delta$ opioid receptor," Journal of Biological Chemistry, vol. 281, no. 23, pp. 1578015789, 2006.

[130] K. Mackie, "Cannabinoid receptors: where they are and what they do," Journal of Neuroendocrinology, vol. 20, no. s1, pp. 10-14, 2008.

[131] A. C. Howlett, F. Barth, T. I. Bonner et al., "International Union of Pharmacology. XXVII. Classification of cannabinoid receptors," Pharmacological Reviews, vol. 54, no. 2, pp. 161-202, 2002.

[132] B. D. Winters, J. M. Kruger, X. Huang et al., "Cannabinoid receptor 1-expressing neurons in the nucleus accumbens," Proceedings of the National Academy of Sciences of the United States of America, vol. 109, no. 40, pp. E2717-E2725, 2012.

[133] T. T.-Y. Lee, M. N. Hill, C. J. Hillard, and B. B. Gorzalka, "Disruption of peri-adolescent endocannabinoid signaling modulates adult neuroendocrine and behavioral responses to stress in male rats," Neuropharmacology, vol. 99, pp. 8997, 2015.

[134] M. Méndez-Díaz, S. Caynas-Rojas, V. Arteaga Santacruz, A. E. Ruiz-Contreras, R. Aguilar-Roblero, and O. ProspéroGarcía, "Entopeduncular nucleus endocannabinoid system modulates sleep-waking cycle and mood in rats," Pharmacology Biochemistry and Behavior, vol. 107, pp. 29-35, 2013.

[135] M. Loureiro, J. Renard, J. Zunder, and S. R. Laviolette, "Hippocampal cannabinoid transmission modulates dopamine 
neuron activity: impact on rewarding memory formation and social interaction," Neuropsychopharmacology, vol. 40, no. 6, pp. 1436-1447, 2015.

[136] S. Oddi, E. Dainese, S. Sandiford et al., "Effects of palmitoylation of $\mathrm{Cys}^{415}$ in helix 8 of the $\mathrm{CB}_{1}$ cannabinoid receptor on membrane localization and signalling," British Journal of Pharmacology, vol. 165, no. 8, pp. 2635-2651, 2012.

[137] L. A. Volpicelli and A. I. Levey, "Muscarinic acetylcholine receptor subtypes in cerebral cortex and hippocampus," Progress in Brain Research, vol. 145, pp. 59-66, 2004.

[138] P. Abrams, K. E. Andersson, J. J. Buccafusco et al., "Muscarinic receptors: their distribution and function in body systems, and the implications for treating overactive bladder," British Journal of Pharmacology, vol. 148, no. 5, pp. 565578, 2006.

[139] E. T. Tzavara, F. P. Bymaster, C. C. Felder et al., "Dysregulated hippocampal acetylcholine neurotransmission and impaired cognition in M2, M4 and M2/M4 muscarinic receptor knockout mice," Molecular Psychiatry, vol. 8, no. 7, pp. 673-679, 2003.

[140] T. Seeger, I. Fedorova, F. Zheng et al., " $\mathrm{M}_{2}$ muscarinic acetylcholine receptor knock-out mice show deficits in behavioral flexibility, working memory, and hippocampal plasticity," The Journal of Neuroscience, vol. 24, no. 45, pp. 1011710127, 2004.

[141] C. J. van Koppen and N. M. Nathanson, "The cysteine residue in the carboxyl-terminal domain of the $\mathrm{m}_{2}$ muscarinic acetylcholine receptor is not required for receptor-mediated inhibition of adenylate cyclase," Journal of Neurochemistry, vol. 57, no. 6, pp. 1873-1877, 1991.

[142] T. M. Savarese, C. D. Wang, and C. M. Fraser, "Site-directed mutagenesis of the rat $\mathrm{ml}$ muscarinic acetylcholine receptor. Role of conserved cysteines in receptor function," Journal of Biological Chemistry, vol. 267, no. 16, pp. 1143911448, 1992.

[143] M. K. Hayashi and T. Haga, "Palmitoylation of muscarinic acetylcholine receptor $\mathrm{m} 2$ subtypes: reduction in their ability to activate $\mathrm{G}$ proteins by mutation of a putative palmitoylation site, cysteine 457, in the carboxyl-terminal tail," Archives of Biochemistry and Biophysics, vol. 340, no. 2, pp. 376-382, 1997.

[144] M. A. Bahry, V. S. Chowdhury, H. Yang et al., "Central administration of neuropeptide $\mathrm{Y}$ differentially regulates monoamines and corticosterone in heat-exposed fed and fasted chicks," Neuropeptides, vol. 62, pp. 93-100, 2017.

[145] J. Li, Y. Tian, and A. Wu, "Neuropeptide Y receptors: a promising target for cancer imaging and therapy," Regenerative Biomaterials, vol. 2, no. 3, pp. 215-219, 2015.

[146] E. L. Sabban, L. I. Serova, L. G. Alaluf, M. Laukova, and C. Peddu, "Comparative effects of intranasal neuropeptide $\mathrm{Y}$ and HS014 in preventing anxiety and depressive-like behavior elicited by single prolonged stress," Behavioural Brain Research, vol. 295, pp. 9-16, 2015.

[147] K. T. Nakhate, S. U. Yedke, A. P. Bharne, N. K. Subhedar, and D. M. Kokare, "Evidence for the involvement of neuropeptide $\mathrm{Y}$ in the antidepressant effect of imipramine in type 2 diabetes," Brain Research, vol. 1646, pp. 1-11, 2016.

[148] C. Cabrele and A. G. Beck-Sickinger, "Molecular characterization of the ligand-receptor interaction of the neuropeptide Y family," Journal of Peptide Science, vol. 6, no. 3, pp. 97-122, 2000.
[149] N. D. Holliday and H. M. Cox, "Control of signalling efficacy by palmitoylation of the rat $\mathrm{Y}_{1}$ receptor," British Journal of Pharmacology, vol. 139, no. 3, pp. 501-512, 2003.

[150] R. J. Reiter, "The melatonin rhythm: both a clock and a calendar," Experientia, vol. 49, no. 8, pp. 654-664, 1993.

[151] E. Savaskan, A. Wirz-Justice, G. Olivieri et al., "Distribution of melatonin MT1 receptor immunoreactivity in human retina," Journal of Histochemistry \& Cytochemistry, vol. 50, no. 4, pp. 519-525, 2002.

[152] R. J. Reiter, R. M. Sainz, S. Lopez-Burillo, J. C. Mayo, L. C. Manchester, and D. X. Tan, "Melatonin ameliorates neurologic damage and neurophysiologic deficits in experimental models of stroke," Annals of the New York Academy of Sciences, vol. 993, no. 1, pp. 35-47, 2003.

[153] R. J. Reiter, D. Acuña-Castroviejo, D. X. Tan, and S. Burkhardt, "Free radical-mediated molecular damage. Mechanisms for the protective actions of melatonin in the central nervous system," Annals of the New York Academy of Sciences, vol. 939, pp. 200-215, 2001.

[154] P. Brunner, N. Sözer-Topcular, R. Jockers et al., "Pineal and cortical melatonin receptors MT1 and MT2 are decreased in Alzheimer's disease," European Journal of Histochemistry, vol. 50, no. 4, pp. 311-316, 2006.

[155] C. Ekmekcioglu, "Melatonin receptors in humans: biological role and clinical relevance," Biomedicine \& Pharmacotherapy, vol. 60, no. 3, pp. 97-108, 2006.

[156] S. Sethi, W. Adams, J. Pollock, and P. A. Witt-Enderby, "C-terminal domains within human $\mathrm{MT}_{1}$ and $\mathrm{MT}_{2}$ melatonin receptors are involved in internalization processes," Journal of Pineal Research, vol. 45, no. 2, pp. 212-218, 2008.

[157] M. Hollmann and S. Heinemann, "Cloned glutamate receptors," Annual Review of Neuroscience, vol. 17, no. 1, pp. 31-108, 1994.

[158] P. H. Seeburg, "The TiPS/TINS lecture: the molecular biology of mammalian glutamate receptor channels," Trends in Pharmacological Sciences, vol. 14, no. 8, pp. 297-303, 1993.

[159] M. Constantine-Paton, H. T. Cline, and E. Debski, "Patterned activity, synaptic convergence, and the NMDA receptor in developing visual pathways," Annual Review of Neuroscience, vol. 13, no. 1, pp. 129-154, 1990.

[160] L. Caffino, M. Frankowska, G. Giannotti et al., "Cocaineinduced glutamate receptor trafficking is abrogated by extinction training in the rat hippocampus," Pharmacological Reports, vol. 66, no. 2, pp. 198-204, 2014.

[161] S. Goodwani, H. Saternos, F. Alasmari, and Y. Sari, "Metabotropic and ionotropic glutamate receptors as potential targets for the treatment of alcohol use disorder," Neuroscience \& Biobehavioral Reviews, vol. 77, pp. 14-31, 2017.

[162] R. Cannady, K. R. Fisher, C. Graham, J. Crayle, J. Besheer, and C. W. Hodge, "Potentiation of amygdala AMPA receptor activity selectively promotes escalated alcohol selfadministration in a CaMKII-dependent manner," Addiction Biology, vol. 22, no. 3, pp. 652-664, 2017.

[163] X. Q. Wang, X. L. Zhong, Z. B. Li et al., "Differential roles of hippocampal glutamatergic receptors in neuropathic anxietylike behavior after partial sciatic nerve ligation in rats," $B M C$ Neuroscience, vol. 16, no. 1, p. 14, 2015.

[164] P. De Rossi, E. Harde, J. P. Dupuis et al., "A critical role for VEGF and VEGFR2 in NMDA receptor synaptic function and fear-related behavior," Molecular Psychiatry, vol. 21, no. 12, pp. 1768-1780, 2016. 
[165] G. S. B. Aseervatham, U. Suryakala, Doulethunisha, S. Sundaram, P. C. Bose, and T. Sivasudha, "Expression pattern of NMDA receptors reveals antiepileptic potential of apigenin 8-C-glucoside and chlorogenic acid in pilocarpine induced epileptic mice," Biomedicine \& Pharmacotherapy, vol. 82, pp. 54-64, 2016.

[166] K. Fujihara, H. Miwa, T. Kakizaki et al., "Glutamate decarboxylase 67 deficiency in a subset of GABAergic neurons induces schizophrenia-related phenotypes," Neuropsychopharmacology, vol. 40, no. 10, pp. 2475-2486, 2015.

[167] S. B. Liu, M. M. Zhang, L. F. Cheng, J. Shi, J. S. Lu, and M. Zhuo, "Long-term upregulation of cortical glutamatergic AMPA receptors in a mouse model of chronic visceral pain," Molecular Brain, vol. 8, no. 1, p. 76, 2015.

[168] V. Anggono and R. L. Huganir, "Regulation of AMPA receptor trafficking and synaptic plasticity," Current Opinion in Neurobiology, vol. 22, no. 3, pp. 461-469, 2012.

[169] R. C. Malenka and M. F. Bear, "LTP and LTD: an embarrassment of riches," Neuron, vol. 44, no. 1, pp. 5-21, 2004.

[170] T. Hayashi, G. Rumbaugh, and R. L. Huganir, "Differential regulation of AMPA receptor subunit trafficking by palmitoylation of two distinct sites," Neuron, vol. 47, no. 5, pp. 709-723, 2005.

[171] C. Fang, L. Deng, C. A. Keller et al., "GODZ-mediated palmitoylation of $\mathrm{GABA}_{\mathrm{A}}$ receptors is required for normal assembly and function of GABAergic inhibitory synapses," The Journal of Neuroscience, vol. 26, no. 49, pp. 12758-12768, 2006.

[172] G. Yang, W. Xiong, L. Kojic, and M. S. Cynader, "Subunitselective palmitoylation regulates the intracellular trafficking of AMPA receptor," European Journal of Neuroscience, vol. 30, no. 1, pp. 35-46, 2009.

[173] S. G. Cull-Candy and D. N. Leszkiewicz, "Role of distinct NMDA receptor subtypes at central synapses," Science Signaling, vol. 2004, no. 255, article re16, 2004.

[174] R. Dingledine, K. Borges, D. Bowie, and S. F. Traynelis, "The glutamate receptor ion channels," Pharmacological Reviews, vol. 51, no. 1, pp. 7-61, 1999.

[175] H. Mori and M. Mishina, "Structure and function of the NMDA receptor channel," Neuropharmacology, vol. 34, no. 10, pp. 1219-1237, 1995.

[176] T. Hayashi, G. M. Thomas, and R. L. Huganir, "Dual palmitoylation of NR2 subunits regulates NMDA receptor trafficking," Neuron, vol. 64, no. 2, pp. 213-226, 2009.

[177] H. A. Mattison, T. Hayashi, and A. Barria, "Palmitoylation at two cysteine clusters on the C-terminus of GluN2A and GluN2B differentially control synaptic targeting of NMDA receptors," PLoS One, vol. 7, no. 11, article e49089, 2012.

[178] D. S. Pickering, F. A. Taverna, M. W. Salter, and D. R. Hampson, "Palmitoylation of the GluR6 kainate receptor," Proceedings of the National Academy of Sciences of the United State of America, vol. 92, no. 26, pp. 12090-12094, 1995.

[179] B. A. Copits and G. T. Swanson, "Kainate receptor posttranslational modifications differentially regulate association with $4.1 \mathrm{~N}$ to control activity-dependent receptor endocytosis," Journal of Biological Chemistry, vol. 288, no. 13, pp. 8952-8965, 2013.

[180] P. J. Whiting, R. M. McKernan, and K. A. Wafford, "Structure and pharmacology of vertebrate $\mathrm{GABA}_{\mathrm{A}}$ receptor subtypes," International Review of Neurobiology, vol. 38, pp. 95-138, 1995.
[181] G. Rodriguez-Manzo and A. Canseco-Alba, “A new role for GABAergic transmission in the control of male rat sexual behavior expression," Behavioural Brain Research, vol. 320, pp. 21-29, 2017.

[182] C. P. Almeida-Suhett, E. M. Prager, V. Pidoplichko et al., "Reduced GABAergic inhibition in the basolateral amygdala and the development of anxiety-like behaviors after mild traumatic brain injury," PLoS One, vol. 9, no. 7, article e102627, 2014.

[183] G. Quadrato, M. Y. Elnaggar, C. Duman, A. Sabino, K. Forsberg, and S. di Giovanni, "Modulation of GABAA receptor signaling increases neurogenesis and suppresses anxiety through NFATc4," The Journal of Neuroscience, vol. 34, no. 25, pp. 8630-8645, 2014.

[184] A. Paydar, B. Lee, G. Gangadharan, S. Lee, E. Hwang, and H. S. Shin, "Extrasynaptic $\mathrm{GABA}_{\mathrm{A}}$ receptors in mediodorsal thalamic nucleus modulate fear extinction learning," Molecular Brain, vol. 7, no. 1, p. 39, 2014.

[185] J. M. Kim, D. H. Kim, Y. Lee, S. J. Park, and J. H. Ryu, “Distinct roles of the hippocampus and perirhinal cortex in $\mathrm{GABA}_{\mathrm{A}}$ receptor blockade-induced enhancement of object recognition memory," Brain Research, vol. 1552, pp. 17-25, 2014.

[186] S. Brailowsky and O. Garcia, "Ethanol, GABA and epilepsy," Archives of Medical Research, vol. 30, no. 1, pp. 3-9, 1999.

[187] J. Rathenberg, J. T. Kittler, and S. J. Moss, "Palmitoylation regulates the clustering and cell surface stability of $\mathrm{GABA}_{\mathrm{A}}$ receptors," Molecular and Cellular Neuroscience, vol. 26, no. 2, pp. 251-257, 2004.

[188] C. A. Keller, X. Yuan, P. Panzanelli et al., "The $\gamma 2$ subunit of $\mathrm{GABA}_{\mathrm{A}}$ receptors is a substrate for palmitoylation by GODZ," The Journal of Neuroscience, vol. 24, no. 26, pp. 5881-5891, 2004.

[189] C. L. Kilpatrick, S. Murakami, M. Feng et al., "Dissociation of Golgi-associated DHHC-type zinc finger protein (GODZ)and Sertoli cell gene with a zinc finger domain- $\beta$ (SERZ- $\beta$ )mediated palmitoylation by loss of function analyses in knock-out mice," Journal of Biological Chemistry, vol. 291, no. 53, pp. 27371-27386, 2016.

[190] I. Posadas, B. Lopez-Hernandez, and V. Cena, "Nicotinic receptors in neurodegeneration," Current Neuropharmacology, vol. 11, no. 3, pp. 298-314, 2013.

[191] J. A. Dani, "Neuronal nicotinic acetylcholine receptor structure and function and response to nicotine," International Review of Neurobiology, vol. 124, pp. 3-19, 2015.

[192] M. R. Picciotto, M. J. Higley, and Y. S. Mineur, "Acetylcholine as a neuromodulator: cholinergic signaling shapes nervous system function and behavior," Neuron, vol. 76, no. 1, pp. 116-129, 2012.

[193] S. L. McLean, B. Grayson, S. Marsh, S. H. O. Zarroug, M. K. Harte, and J. C. Neill, "Nicotinic $\alpha 7$ and $\alpha 4 \beta 2$ agonists enhance the formation and retrieval of recognition memory: potential mechanisms for cognitive performance enhancement in neurological and psychiatric disorders," Behavioural Brain Research, vol. 302, pp. 73-80, 2016.

[194] S. I. Deutsch, J. A. Burket, M. R. Urbano, and A. D. Benson, "The $\alpha_{7}$ nicotinic acetylcholine receptor: a mediator of pathogenesis and therapeutic target in autism spectrum disorders and Down syndrome," Biochemical Pharmacology, vol. 97, no. 4, pp. 363-377, 2015. 
[195] J. K. Alexander, A. P. Govind, R. C. Drisdel et al., "Palmitoylation of nicotinic acetylcholine receptors," Journal of Molecular Neuroscience, vol. 40, no. 1-2, pp. 12-20, 2010.

[196] R. C. Drisdel, E. Manzana, and W. N. Green, "The role of palmitoylation in functional expression of nicotinic $\alpha 7$ receptors," The Journal of Neuroscience, vol. 24, no. 46, pp. 10502-10510, 2004.

[197] S. A. Amici, S. B. McKay, G. B. Wells et al., "A highly conserved cytoplasmic cysteine residue in the $\alpha 4$ nicotinic acetylcholine receptor is palmitoylated and regulates protein expression," Journal of Biological Chemistry, vol. 287, no. 27, pp. 23119-23127, 2012.

[198] B. Sperlagh and P. Illes, "P2X7 receptor: an emerging target in central nervous system diseases," Trends in Pharmacological Sciences, vol. 35, no. 10, pp. 537-547, 2014.

[199] B. Sperlagh, C. Csolle, R. D. Ando, F. Goloncser, A. Kittel, and M. Baranyi, "The role of purinergic signaling in depressive disorders," Neuropsychopharmacologia Hungarica, vol. 14, no. 4, pp. 231-238, 2012.

[200] P. Gonnord, C. Delarasse, R. Auger et al., "Palmitoylation of the P2X7 receptor, an ATP-gated channel, controls its expression and association with lipid rafts," The FASEB Journal, vol. 23, no. 3, pp. 795-805, 2009.

[201] S. S. Sanders and M. R. Hayden, "Aberrant palmitoylation in Huntington disease," Biochemical Society Transactions, vol. 43, no. 2, pp. 205-210, 2015.

[202] J. Noritake, Y. Fukata, T. Iwanaga et al., "Mobile DHHC palmitoylating enzyme mediates activity-sensitive synaptic targeting of PSD-95," The Journal of Cell Biology, vol. 186, no. 1, pp. 147-160, 2009. 


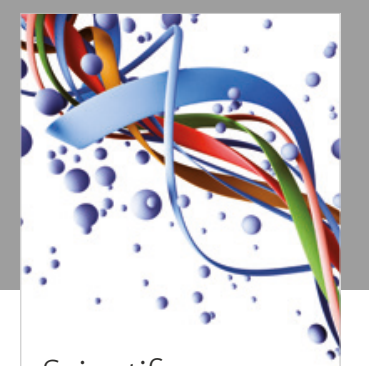

Scientifica
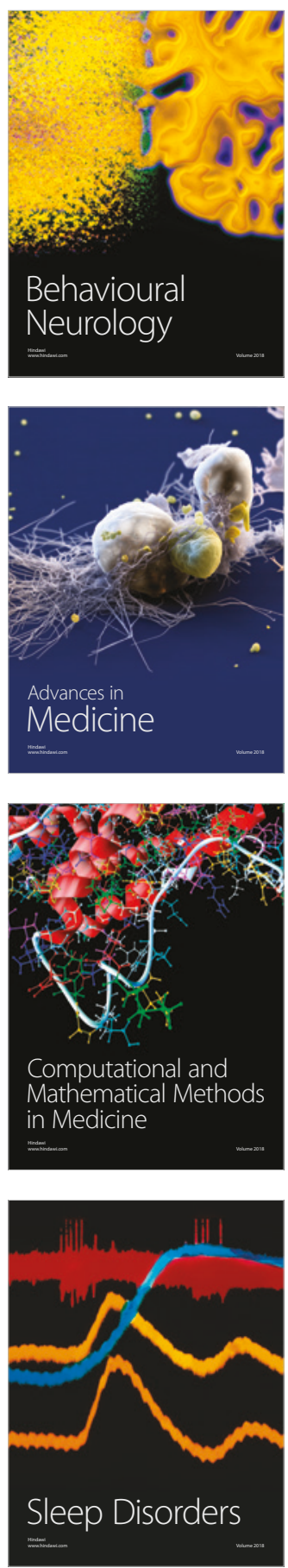

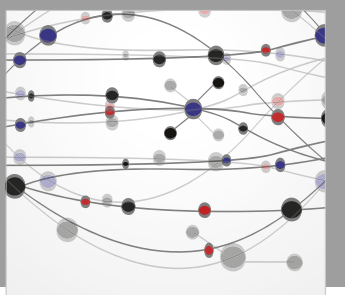

The Scientific World Journal

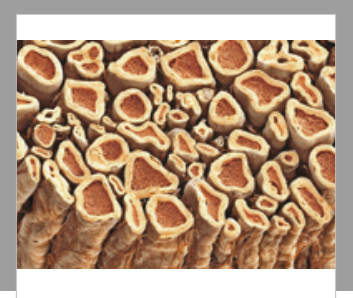

Case Reports in

Neurological Medicine

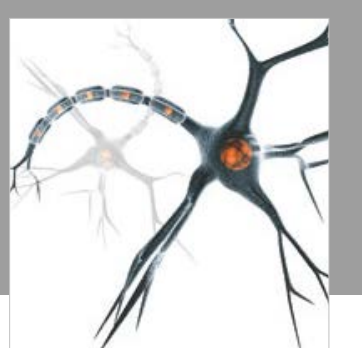

Neural Plasticity

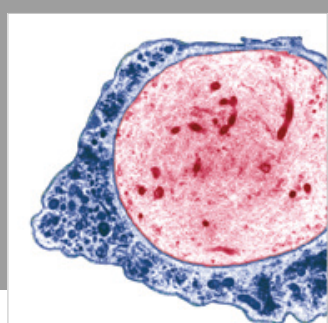

Multiple Sclerosis

International

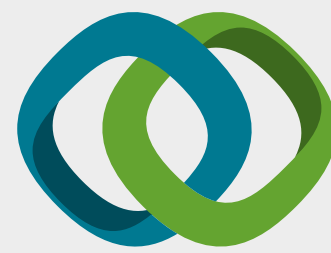

Hindawi

Submit your manuscripts at

www.hindawi.com
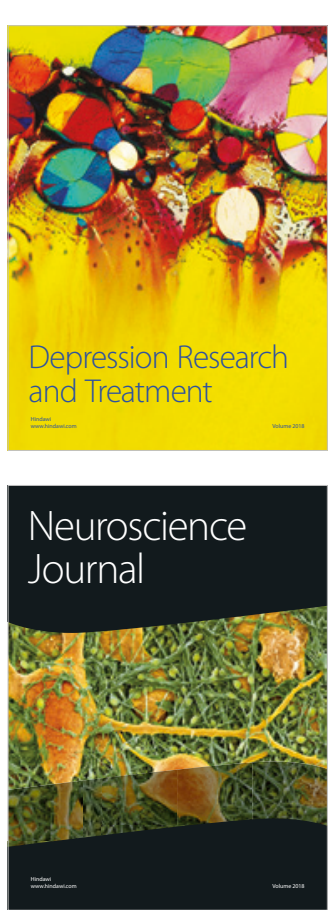

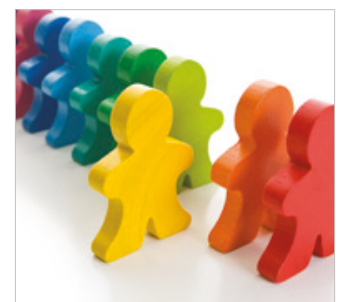

Autism

Research and Treatment
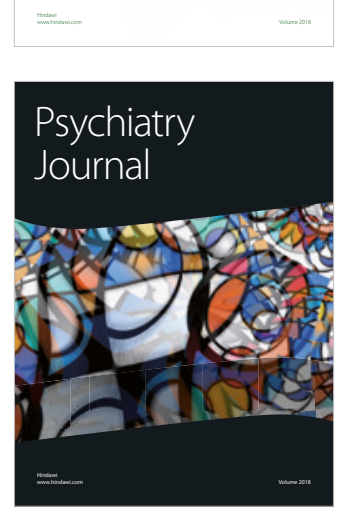
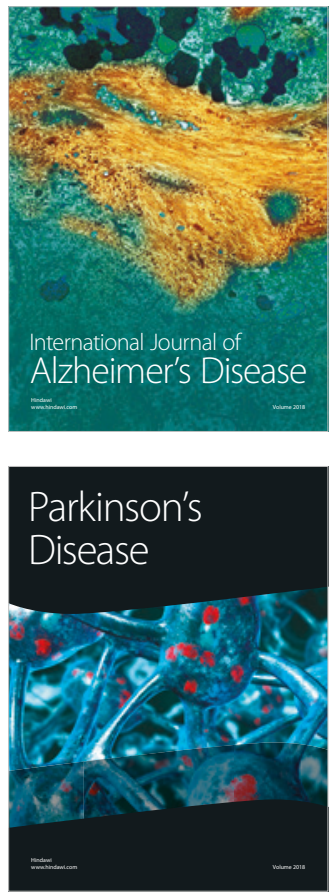
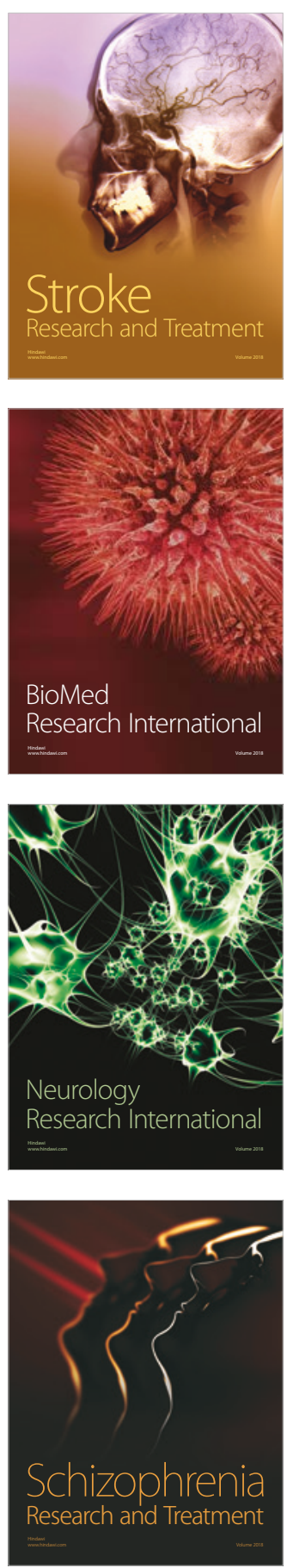